\title{
Mesoscale Distribution of Springtime Waters and Nutrients near the Continental Shelf Break, Beaufort Sea, Alaska
}

\author{
John P. Christensen ${ }^{*}, 1$ and Humfrey Melling ${ }^{2}$ \\ ${ }^{I}$ Bigelow Laboratory for Ocean Sciences, 180 McKown Point, P.O. Box 475, West Boothbay Harbor, Maine $04575-$ \\ 0475, USA \\ ${ }^{2}$ Fisheries and Oceans Canada, Institute of Ocean Sciences, 9860 West Saanich Road, P.O. Box 6000, Sidney, B.C., \\ V8L4B2, Canada
}

\begin{abstract}
Forty two sites on the Alaskan Beaufort Sea shelf break were sampled by helicopter in April 2003 for hydrographic parameters and nutrients. Mesoscale maps delineated two eddies and the Beaufort shelf break current. Higher-salinity nutrient-rich waters upwelled onto the shelf, and the depth of the main pycnocline shoaled to $<22 \mathrm{~m}$. A plume of 31.40-31.80 salinity water at $10 \mathrm{~m}$ was flowing off the shelf, and maps of Brunt Vaisala frequencies and Richardson numbers showed that its presence weakened the pycnocline stability. The high shelf-break nutrient concentrations could support a spring-bloom productivity of $23 \mathrm{~g}-\mathrm{C} \mathrm{m}^{-2} \mathrm{y}^{-1}$, which, when added to previous summertime productivity measurements, demonstrated significant production along the Beaufort Sea shelf break.
\end{abstract}

Keywords: Shelfbreak upwelling, nutrients, CTD observations, mesoscale eddies, arctic ocean, beaufort sea.

\section{INTRODUCTION}

The Beaufort Sea, northern Chukchi Sea, and the Canada Basin have been thought to be extremely oligotrophic, with productivities approximating 20-50 g-C m ${ }^{-2} \mathrm{y}^{-1}$ [1-7]. Early studies suggested that this was due to light limitation since the nearly permanent Arctic ice-pack prevented significant solar irradiance inputs to the ocean waters [8-10]. Also, nutrient concentrations in surface waters exceeded those considered to be limiting [9].

Recent studies have shown that both the sea-ice extent [11-14] and thickness [15,16] have diminished in the last several decades. Because snow and ice attenuate light more than water alone (about 10 times more for ice and 100 times more for snow), reduction in the extent or thickness can greatly increase the light available for photosynthesis. Typically, sea-ice in the Canada Basin, with an ice thickness of $2.3 \mathrm{~m}$ overlain by $2-3 \mathrm{~cm}$ of snow, allows $3 \%$ of the above-ice irradiance to enter the ocean waters [7]. The 1-m decrease in ice thickness reported by Rothrock et al. [16] would increase light intensity below the ice by $25 \%$. In cases where ice was completely removed in summer, the light level would increase over 10-100 fold in the upper water column [17,18], which could increase the depth of the euphotic zone to over $50 \mathrm{~m}$.

Given the concept that light was limiting in the extremely oligotrophic Arctic, the possible role of significant nutrient limitation was not entertained in the early literature [19]. However, the widespread occurrence of nutrient limitation was dramatically encountered in the offshore Canada Basin during the year long Surface Heat and Energy Budget of the

*Address correspondence to this author at the Bigelow Laboratory for Ocean Sciences, 180 McKown Point, P.O. Box 475, West Boothbay Harbor, Maine 04575-0475, USA; Tel: (207) 633-9601; Fax: (207) 633-9641; E-mail: jchristensen@bigelow.org
Arctic (SHEBA) study in the offshore Canada Basin. That study found that the dramatic melting of sea ice within the Basin in summer of 1997 increased the stratification of the surface layer [20]. As a result, nitrate concentrations in the upper $50 \mathrm{~m}$ were less than $0.5 \mu \mathrm{M}$ in the months following the melt event [6]. In addition to the SHEBA results, more frequent summer-time sampling had shown nutrient-limiting conditions in late summer in both the Beaufort and Chukchi Seas and in the offshore Canada Basin $[4,7,21,22]$. Concerning climate change in the Arctic, one could argue that a sequence of linked events has occurred. Climate change fostered reductions in ice extent and thickness, and this promoted increased productivity and increased nutrient uptake. Increasing productivity then produced the conditions of summer-time nutrient limitation possibly over large areas of the Canada Basin and its adjoining shelf seas. On the other hand, the early view, that nutrient concentrations remained sufficient under the sea-ice, should be suspect since one early study reported summer-time nutrient reductions along the Beaufort continental shelf and in the mid and northern Chukchi Sea [23]. Also, nitrate concentrtions less than $1 \mu \mathrm{M}$ had been reported under the central Arctic ice pack in late summer $[4,24]$. So, one could also argue that nutrient limitation may have occurred in past decades but went unseen because of the lack of ship access in these remote ice covered regions or because of the poorer quality nutrient methods prior to the 1970's.

In addition to the issues of light versus nutrient limitation, there also may be uncertainty with regard to the magnitude of the annual primary production. In the offshore Canada Basin, long term estimates of annual productivity were made based on the seasonal development of oxygen concentration maxima in surface waters under the ice [5] and based on carbon oxidation rates in the deep waters $(>1500$ $\mathrm{m})$ of the Canada Basin $[25,26]$. For the offshore region, both approaches yielded annual productivities of 10-30 g-C 
$\mathrm{m}^{-2} \mathrm{y}^{-1}$. Most other studies have used productivity incubations taken during the occasional icebreaker cruises $[2,3,6,7]$, cruises that traditionally occur in summer because of the less extensive ice cover and that follow ship tracks which precluded single-site time-series measurements. The SHEBA experiment had been the one attempt at determining the annual productivity via time series at a single site. Here the science-laden icebreaker began its year-long drift in the central Canada Basin in November 1997. As mentioned above, during the initial months in fall and winter 1997, nutrients were found to be extremely low in the central Canada Basin. However, by spring-time, the ship had drifted out of the central Basin and over the Chukchi Plateau, where hydrographic conditions differed, nutrients were more plentiful, and productivity was enhanced [6]. Thus, the ship's drift into a distinctly different hydrographic regime prevented the attainment of the Canadian Basin time-series. A more recent program, the Shelf-Basin Interactions Program (SBI) employed an icebreaker for two cruises, the first in early June and the second in August, in order to define better the seasonality in productivity. In summer 2003, the areal average productivity over the northern Chukchi and western Beaufort shelf break region was $70 \mathrm{~g}-\mathrm{C} \mathrm{m}^{-2} \mathrm{y}^{-1}$, greater than found in previous studies, while the average over the southern Canada Basin remained low $\left(20 \mathrm{~g}-\mathrm{C} \mathrm{m}^{-2} \mathrm{y}^{-1}\right.$, [27]). But even with early June sampling, the ship apparently missed the nutrient-driven spring bloom so that their annual average underestimated the annual productivity [27].

Implicit in the argument for low productivity in the Canada Basin was the presupposition of a regionally uniform and highly stable euphotic zone. But are there sites where physical processes occasionally break down the strong stratification that characterizes the Canada Basin? If these sites exist, it is possible that nutrient inputs to the euphotic zone could be significant and could support moderate or high levels of productivity. Given randomly oriented ship-tracks with widely spaced stations, productivity hot spots could easily be missed. One phenomenon that could be important are the sporadic upwelling events which have been reported along the Chukchi and Beaufort shelf edge [23,28-30]. These typically have been detected because of the presence of high salinity waters on the shelves, waters that are typically found in the Basin at depths well below $100 \mathrm{~m}$. These high salinity waters also contain high concentrations of nutrients [22, $23,30]$. Such events typically have short lifetimes (a few days to three weeks) and occur in relatively localized areas, and thus would be easily missed by random shipboard sampling.

A second mechanism which may act to destabilize the upper ocean is the eastward flowing current along the northern Chukchi and Beaufort Sea continental shelves, the Beaufort undercurrent $[31,32]$ or the Beaufort shelfbreak jet [33]. This narrow boundary current occurs in all seasons but appears to carry different waters and have different structures [33]. When carrying warm Chukchi shelf water, strong flow is developed near the sea surface. When carrying winter transformed shelf waters, it is a mid-depth jet (100$150 \mathrm{~m}$ ), but when carrying deeper Atlantic waters, it merges with the deeper eastward flow of the Atlantic water. In the situations where it carries winter shelf water or Atlantic water, these waters may upwell near the shelf break. Since both winter shelf water and Atlantic water are high in nutrients $[22,23,30]$, this current could be significant in the vertical transport of nutrients. In addition, this current is susceptible to baroclinic instabilities that may lead to potentially important mesoscale vertical transports. Furthermore, these instabilities may be responsible for generating smallscale eddies ubiquitous in the Canada Basin [34,35], which because of the high nutrient concentrations in their core waters [36], could also promote nutrient enrichment into the summertime euphotic zone.

As part of the SBI Project, we used helicopter transport to sample a mesoscale region of the Beaufort shelf break in order to locate the Beaufort shelfbreak jet. One goal was to

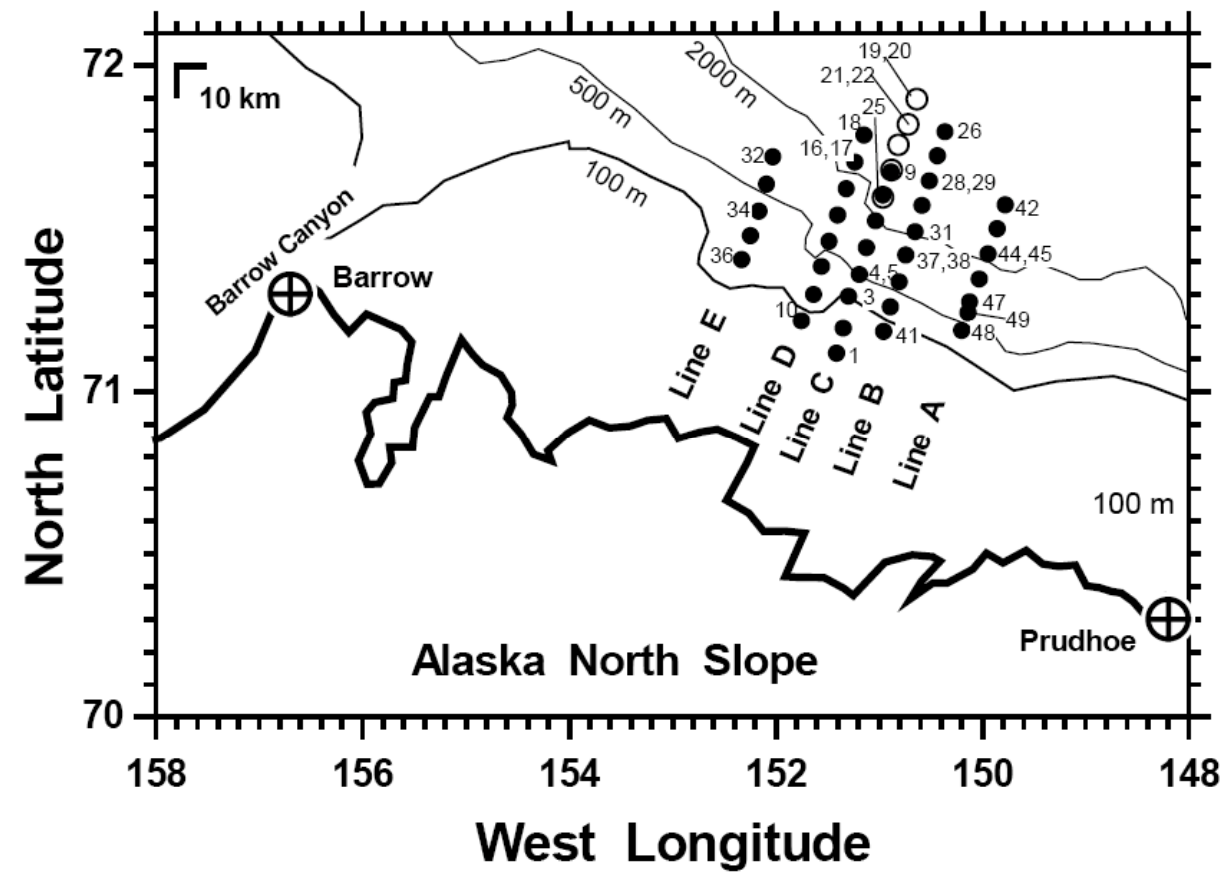

Fig. (1). Locations of CTD casts during April 2003. 
determine if mesoscale variability associated with this jet was significant enough to influence the nutrient distributions within the near-surface waters (within the depth of the summer-time euphotic zone). The effort was done in early April, just 3 weeks after the arrival of lengthy daylight and within a few weeks of the first SBI icebreaker cruise to the area. In April, the sea-ice was thick, and it covered nearly all the sampling area, so productivity likely would not be significant. By determining the nutrient concentrations in the near-surface waters prior to the anticipated spring bloom, the magnitude of spring-bloom production could be estimated. This report describes the oceanographic conditions found in this inaccessible region during this study.

\section{MATERIALS AND METHODS}

On April 2-15, 2003, we used a helicopter to sample 42 sites near the continental shelf break on the Beaufort Sea of northern Alaska (Fig. (1), Table 1). These sites were along five transect lines perpendicular to the $100 \mathrm{~m}$ bathymetric depth. One transect, line C, was sampled a second time (line $\mathrm{C} 2$ ) in order to verify the presence of an eddy. At each site, a $20 \mathrm{~cm}$ diameter hole was augured through the sea-ice (average ice thickness of $138 \mathrm{~cm}$ ). At sites 10-49, a Seabird CTD (SBE 25), linked to an In Situ Ultraviolet Spectrophotometer (ISUS, Satlantic Inc) for measuring nitrate concentrations [37] was connected to a conducting cable, winch, and deck unit. Details of the setup and use of the ISUS were described [38]. The instrument string was deployed through the hole in the sea-ice and vertical profiles to depths of 390 m were measured. At CTD sites 1-9, a Seabird SB19 CTD was used to depths of $175 \mathrm{~m}$.

Water samples were collected from up to 9 depths at a site [38]. From the oceanographic water bottle, $50 \mathrm{ml}$ of seawater were drained into a previously acid-cleaned and thoroughly dry polyethylene sample bottle. From this, $20 \mathrm{ml}$ were pipetted into a clean glass scintillation bottle with polyseal lid, for later measurement of the ${ }^{18} \mathrm{O} /{ }^{16} \mathrm{O}$ ratio of the seawater. The remainder in the polyethylene bottle, about 20 $\mathrm{ml}$, was frozen for later nutrient determinations. The nutrient samples were kept frozen until measurement for concentrations of nitrate, nitrite, ammonium, inorganic phosphate, and dissolved silicate at the Scripps Institute of Oceanography's Nutrient Chemistry Laboratory. This Laboratory operates the nutrient autoanalyzer according to WOCE protocols for accuracy and precision. Of these nutrients, phosphate was not discussed here. Nitrite concentrations were less than 0.15 $\mu \mathrm{M}$ and averaged $0.03 \mu \mathrm{M}$ for all 181 samples, and so were unimportant relative to nitrate concentrations. Similarly, ammonium concentrations were less than $1.40 \mu \mathrm{M}$ and averaged $0.25 \mu \mathrm{M}$, so this nutrient also was not considered here. The ${ }^{18} \mathrm{O} /{ }^{16} \mathrm{O}$ isotopic ratios of the seawater samples $\left(\delta^{18} \mathrm{O},[39]\right)$ were determined at the Stable Isotope Mass Spectrometer Facility at the University of Maine Orono. The average precision of the mass-spectrometer determinations was reported to be $+/-0.013 \%$ for 205 determinations. However, we measured four samples in duplicate and the average standard deviation of these duplicates was $0.075 \%$ $(+/-0.032 \% 0$ as the standard deviation on this average).

The CTD data [40] was processed using SeaSoft postcast processing software from Seabird Inc [38]. Tables of the fully processed data are available in the Arctic System Science (ARCSS) data repository [40]. The freezing point of sea water was calculated following [41] and vertical profiles of the temperature difference between the observed temperature and the freezing point were determined. Geostrophic velocities relative to the $360 \mathrm{~m}$ reference level were calculated from dynamic heights. The use of this reference level would underestimate actual current flows since the deeper Atlantic Water circulation appears to have basin-averaged eastward velocities of $<1 \mathrm{~cm} \mathrm{~s}^{-1}$ [42], but the practicality of using the $360 \mathrm{~m}$ reference level has been discussed [33]. For the vertical sections, the reference level of the stations shallower than $360 \mathrm{~m}$ were selected such that at the bottom of the shallower of two adjacent stations, the current velocity was set to that found at the same depth in the deeper station. For the horizontal maps of geostrophic velocity, a separate procedure for correcting velocities with the $360 \mathrm{~m}$ level was described in the corresponding results section. As a measure of the strength of the density stratification, we calculated vertical profiles of the Brunt Vaisala frequency $\left(\mathrm{N}^{2}, \mathrm{~s}^{-2}\right)$,

$\mathrm{N}_{\mathrm{i}}^{2}=-\left(\mathrm{g} / \rho_{\mathrm{i}}\right) \mathrm{d} \rho_{\mathrm{i}} / \mathrm{dz}$

where $g$ is the gravitational constant $\left(\mathrm{m} \mathrm{s}^{-2}\right)$, the seawater density is $\rho_{\mathrm{i}}$ at depth $z_{\mathrm{i}}$, and $\mathrm{d} \rho_{\mathrm{i}} / \mathrm{dz}$ is the vertical gradient in density [43]. Using profiles smoothed with a 6-m running average, the strength (maximum frequency) and central depth of the main pycnocline were determined.

The nitrate profile data measured by ISUS were processed separately [38]. The ISUS works by measuring the ultraviolet spectra in the region around the nitrate absorption peak at about $220 \mathrm{~nm}$, and then using the spectra to compute an estimated nitrate concentration [37]. The first step in processing of the ISUS profile data was elimination of redundant values. Since the sampling speed of the ISUS is slow (about $0.29 \mathrm{~Hz})$ with respect to the SBE $25 \mathrm{CTD}(8.0$ $\mathrm{Hz}$ ), multiple CTD records following the output of a new ISUS determination contained a single unvarying voltage for nitrate. We eliminated these redundant ISUS voltages and retained only the first nitrate voltage supplied after a new ISUS measurement. The second correction was to shift the ISUS data back in time $(2.3 \mathrm{~s})$ to the approximate time of the spectral scans. Third, we observed both in the laboratory and in this field data that the ISUS output drifted during its first hour of operation. We applied an algorithm which corrected the output voltage to the voltage for the warmed state of the instrument [38]. The resulting ISUS data were binned by pressure, averaged, and the bin pressure moved shallower by 2.5 dbar relative the CTD data based on the difference in height between the ISUS sensor (adjacent to the water sampling bottle) and the CTD sensors. Finally, at each station, the ISUS voltages at water bottle depths were regressed against the bottle-measured nitrate concentrations, and the final ISUS voltage profile was converted to ISUSestimated nitrate concentrations. The difference between the ISUS-estimated profile and the bottle nitrate concentration was found to average $0.0 \mu \mathrm{M}(+/-0.28 \mu \mathrm{M}$ standard deviation for 143 bottle samples), indicating that the ISUS reproduced the bottle concentrations within $+/-0.28 \mu \mathrm{M}$ [38]. Tables of the fully processed data are available at the ARCSS data repository $[44,45]$. 
Table 1. Station Locations, Depths of the CTD Casts, and Ice Thickness in April 2003. No Measurement Equals a Value of -99

\begin{tabular}{|c|c|c|c|c|}
\hline CTD\# & Latitude $\left({ }^{\circ} \mathbf{N}\right)$ & Longitude $\left({ }^{\circ} \mathbf{E}\right)$ & CTD Depth (m) & Ice Depth $(\mathrm{cm})$ \\
\hline 1 & 71.1184 & -151.4100 & 18.1 & -99 \\
\hline 2 & 71.1959 & -151.3448 & 44.4 & -99 \\
\hline 3 & 71.2932 & -151.2928 & 53.3 & -99 \\
\hline 4 & 71.3604 & -151.1895 & 156.4 & -99 \\
\hline 5 & 71.3604 & -151.1895 & 79.2 & -99 \\
\hline 6 & 71.4419 & -151.1215 & 175.2 & -99 \\
\hline 7 & 71.5235 & -151.0332 & 173.9 & -99 \\
\hline 8 & 71.6036 & -150.9624 & 171.5 & -99 \\
\hline 9 & 71.6756 & -150.8832 & 172.6 & -99 \\
\hline 10 & 71.2172 & -151.7486 & 43.8 & 124 \\
\hline 11 & 71.2982 & -151.6306 & 47.6 & 110 \\
\hline 12 & 71.3836 & -151.5579 & 171.0 & -99 \\
\hline 13 & 71.4611 & -151.4855 & 369.9 & -99 \\
\hline 14 & 71.5425 & -151.4014 & 371.8 & 159 \\
\hline 15 & 71.6222 & -151.3149 & 371.6 & 141 \\
\hline 16 & 71.7047 & -151.2346 & 371.7 & 150 \\
\hline 17 & 71.7047 & -151.2346 & 297.3 & 150 \\
\hline 18 & 71.7868 & -151.1452 & 371.7 & -99 \\
\hline 19 & 71.8965 & -150.6321 & 376.7 & 145 \\
\hline 20 & 71.8965 & -150.6321 & 296.5 & 145 \\
\hline 21 & 71.8196 & -150.7189 & 376.6 & -99 \\
\hline 22 & 71.8196 & -150.7189 & 296.8 & -99 \\
\hline 23 & 71.7575 & -150.8093 & 376.3 & 148 \\
\hline 24 & 71.6805 & -150.8776 & 376.8 & -99 \\
\hline 25 & 71.5963 & -150.9603 & 376.6 & -99 \\
\hline 26 & 71.7974 & -150.3615 & 375.8 & 125 \\
\hline 27 & 71.7237 & -150.4321 & 377.1 & 140 \\
\hline 28 & 71.6470 & -150.5118 & 378.2 & 134 \\
\hline 29 & 71.6470 & -150.5118 & 5.8 & 134 \\
\hline 30 & 71.5709 & -150.5832 & 379.2 & 115 \\
\hline 31 & 71.4903 & -150.6492 & 376.6 & 142 \\
\hline 32 & 71.7204 & -152.0252 & 379.6 & 120 \\
\hline 33 & 71.6364 & -152.0901 & 375.6 & -99 \\
\hline 34 & 71.5548 & -152.1635 & 270.0 & 137 \\
\hline 35 & 71.4789 & -152.2465 & 134.6 & 151 \\
\hline 36 & 71.4052 & -152.3267 & 108.4 & 168 \\
\hline 37 & 71.4193 & -150.7395 & 366.3 & 137 \\
\hline 38 & 71.4193 & -150.7395 & 259.9 & 137 \\
\hline 39 & 71.3377 & -150.8033 & 282.7 & 113 \\
\hline 40 & 71.2604 & -150.8908 & 52.3 & -99 \\
\hline
\end{tabular}

(Table 1) Contd.....

\begin{tabular}{|c|c|c|c|c|}
\hline CTD\# & Latitude $\left({ }^{\circ} \mathbf{N}\right)$ & Longitude $\left({ }^{\circ} \mathbf{E}\right)$ & CTD Depth (m) & Ice Depth (cm) \\
\hline \hline 41 & 71.1851 & -150.9558 & 45.4 & 170 \\
\hline 42 & 71.5737 & -149.7784 & 378.8 & 132 \\
\hline 43 & 71.5000 & -149.8560 & 379.6 & 165 \\
\hline 44 & 71.4224 & -149.9430 & 375.6 & 135 \\
\hline 45 & 71.4224 & -149.9430 & 373.8 & 135 \\
\hline 46 & 71.3451 & -150.0303 & 375.2 & 135 \\
\hline 47 & 71.2759 & -150.1249 & 375.1 & 139 \\
\hline 48 & 71.1878 & -150.1991 & 49.8 & 114 \\
\hline 49 & 71.2426 & -150.1364 & 308.4 & -99 \\
\hline
\end{tabular}

\section{RESULTS}

\section{Temperature, Salinity, and Nitrate}

Most oceanographic sampling in the Chukchi and Beaufort Seas has been done in summer, so our data provides a fresh evaluation of the late-winter conditions in this ice-covered region. Traditional water masses found in the Chukchi and western Beaufort continental slope region were identified as inflection points in the diagrams of temperature versus salinity (Fig. 2, [19,22,46,47]). Water masses were layered by salinity from the surface down. These water masses included Arctic Surface Water or Chukchi Surface Water (0-30 m, temperatures near freezing, salinities <31.5), Bering Strait Summer Water, here referred to Chukchi Summer Water (40-70 m, temperatures up to $+1^{\circ} \mathrm{C}$, salinity 32.2-32.7), Upper Halocline Water $(70-90 \mathrm{~m}$, temperatures of -1.4 to $-1.8^{\circ} \mathrm{C}$, salinity $32.7-33.0$ ), Lower Halocline Water (about $180 \mathrm{~m}$, temperatures of 0 to $-1.0^{\circ} \mathrm{C}$, salinity 34.2-34.4), and Atlantic Water (below $300 \mathrm{~m}$, temperatures of +0.4 to $+1.0^{\circ} \mathrm{C}$, salinity $34.7-34.8$, Fig. 3). The temperature-salinity diagram (Fig. 2) showed that these waters, measured in April 2003, corresponded closely to those found in September 1996.

Nitrate concentrations were closely correlated with salinity (Fig. 4 top), although, a minor proportion of the samples had anomalous low nitrate concentrations relative to their salinity. The majority of the depressed concentrations occurred between salinities of 32.6 and 33.6 and these nitrate concentrations were as low as $10 \mu \mathrm{M}$ in comparison with typical concentrations of 12-15.2 $\mu \mathrm{M}$. These anomalies were correlated with cold anomalies in potential temperature (Fig. 4 bottom).

Within T-S diagrams (Fig. 2), the end members or inflection points represent the core of each water mass. For our region, multiple inflection points suggested the occurrence of several water masses that were difficult to distinguish in the typical T-S diagram. Instead, we applied a three-dimensional property plot, using potential temperature, salinity, and nitrate concentration, and this demonstrated eight separate water masses, identified as letters A-H (Table 2, Fig. 5). In Fig. (5), the ideal mixing lines between the water masses were shown, and these were subdivided into two separate assemblies of connected mixing lines. The 


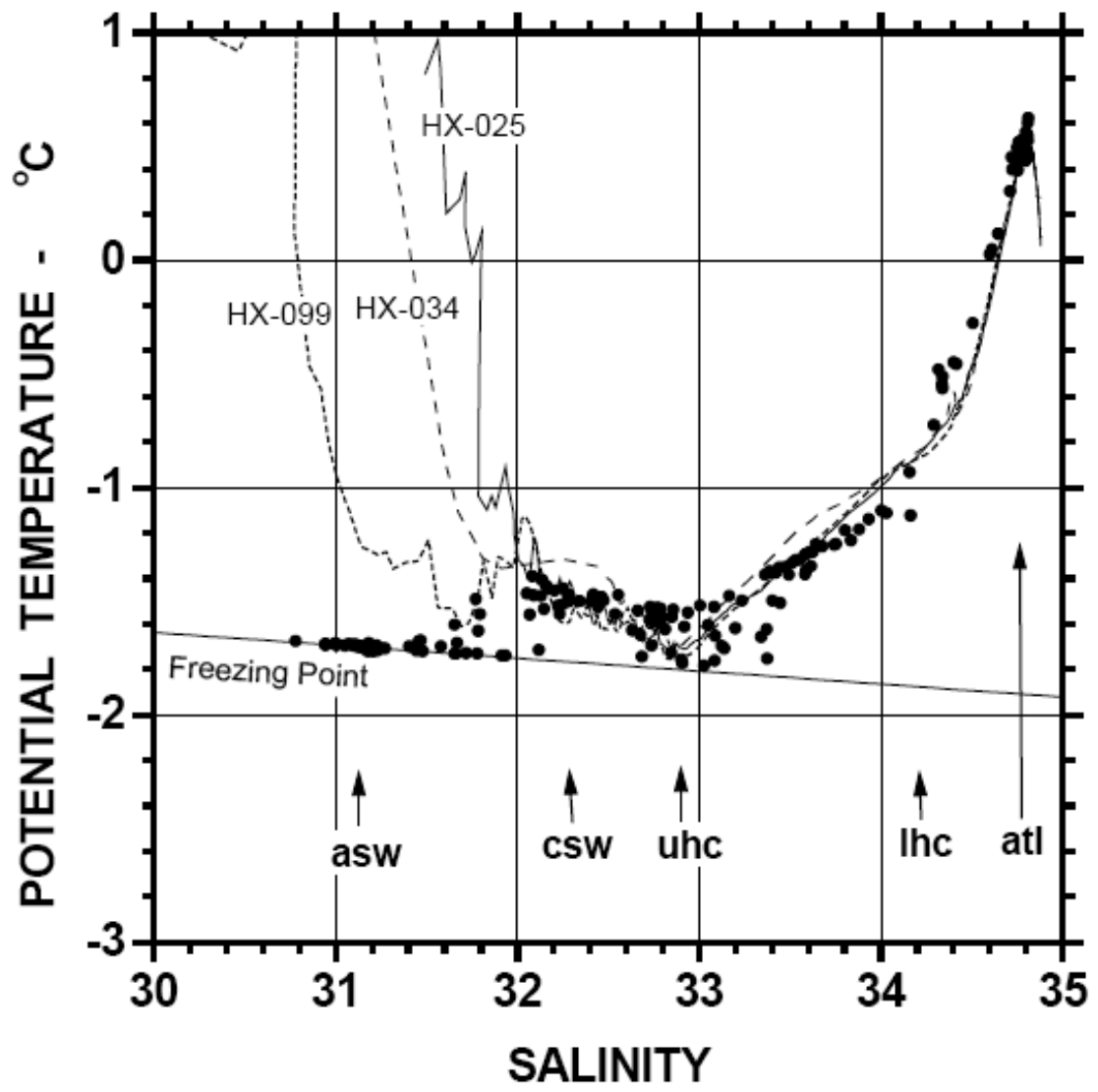

Fig. (2). Relationship between potential temperature $\left({ }^{\circ} \mathrm{C}\right)$ and salinity for all bottle samples. Traditional water masses with their typical salinities include the Arctic Surface Water (asw), Chukchi Summer Water (csw), Upper Halocline Water (uhc), Lower Halocline Water (lhc), and Atlantic Water (atl). Reference lines were profiles (stations HX-025, HX-034, and HX-099) from the continental slope off Barrow, Alaska, in September 1996 [22]. The straight solid line was the freezing point relationship versus salinity.

points, A-E, formed one assembly which included the traditional four waters masses $[19,22,31]$, these being the

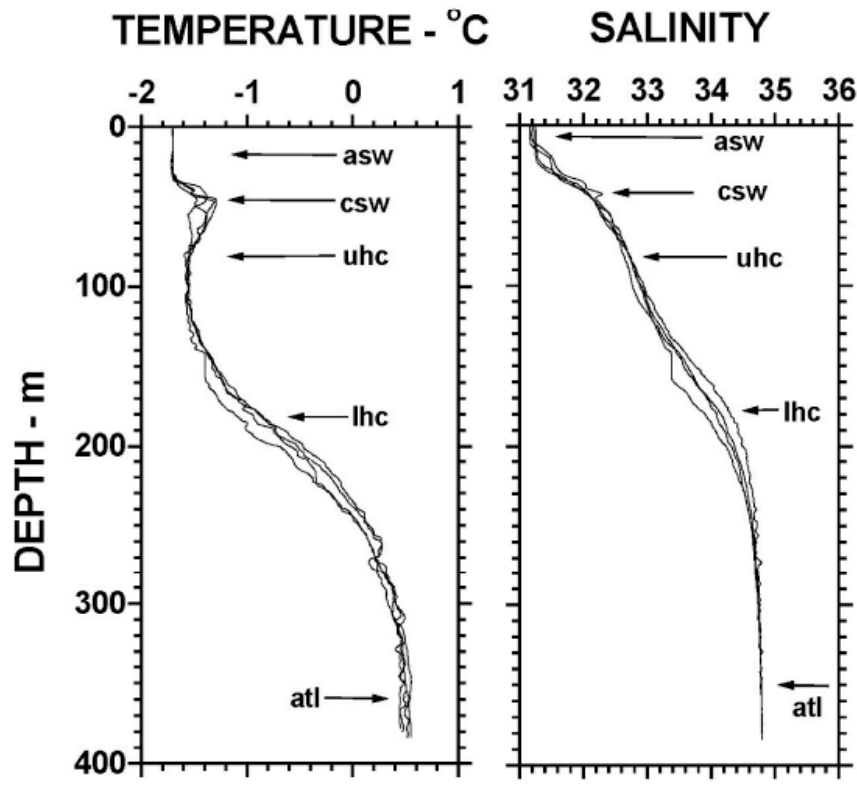

Fig. (3). Vertical profiles of potential temperature and salinity of four characteristic CTD casts (42-45). The core depths of the five traditional water masses were shown.
Atlantic Water (A), the Lower Halocline Water (B), Upper Halocline Water (D), and Surface Water (E). We found a fifth water mass in this assembly, water mass $C$, which corresponded to Middle Halocline Water described by Melling [48] and named by Pickart [33]. The second separate assembly was shown as the sequence of letters, F-H, and this assembly represented waters cooled to the freezing point for the measured salinity. Nearly all of the water samples and most of the continuous profiles fell along indicated mixing lines. For the low salinity surface waters, when salinity was less than that of end-member $\mathrm{E}$, the continuous profiles followed the mixing line $\mathrm{G}-\mathrm{H}$, with the waters at the freezing point. At some depth where salinity exceeded the endmember E, and the temperatures warmed above the freezing point, profiles shifted over to the assembly A-E. The deeper portions of the profiles generally remained above the freezing point and so the properties clustered around assembly A-E. The exceptions were a few vertical regions within some profiles that shifted back toward the freezing point due to intrusions of colder water, as will be described as nutrient anomalies below. This overall correspondence between ideal mixing lines and data was found on all transects measured in this study.

A few bottle samples with anomalous low nitrate concentrations at intermediate salinities had been noted (Fig. 4 top). These anomalies readily appeared in the threedimensional property plots. In Fig. (5), the continuous 

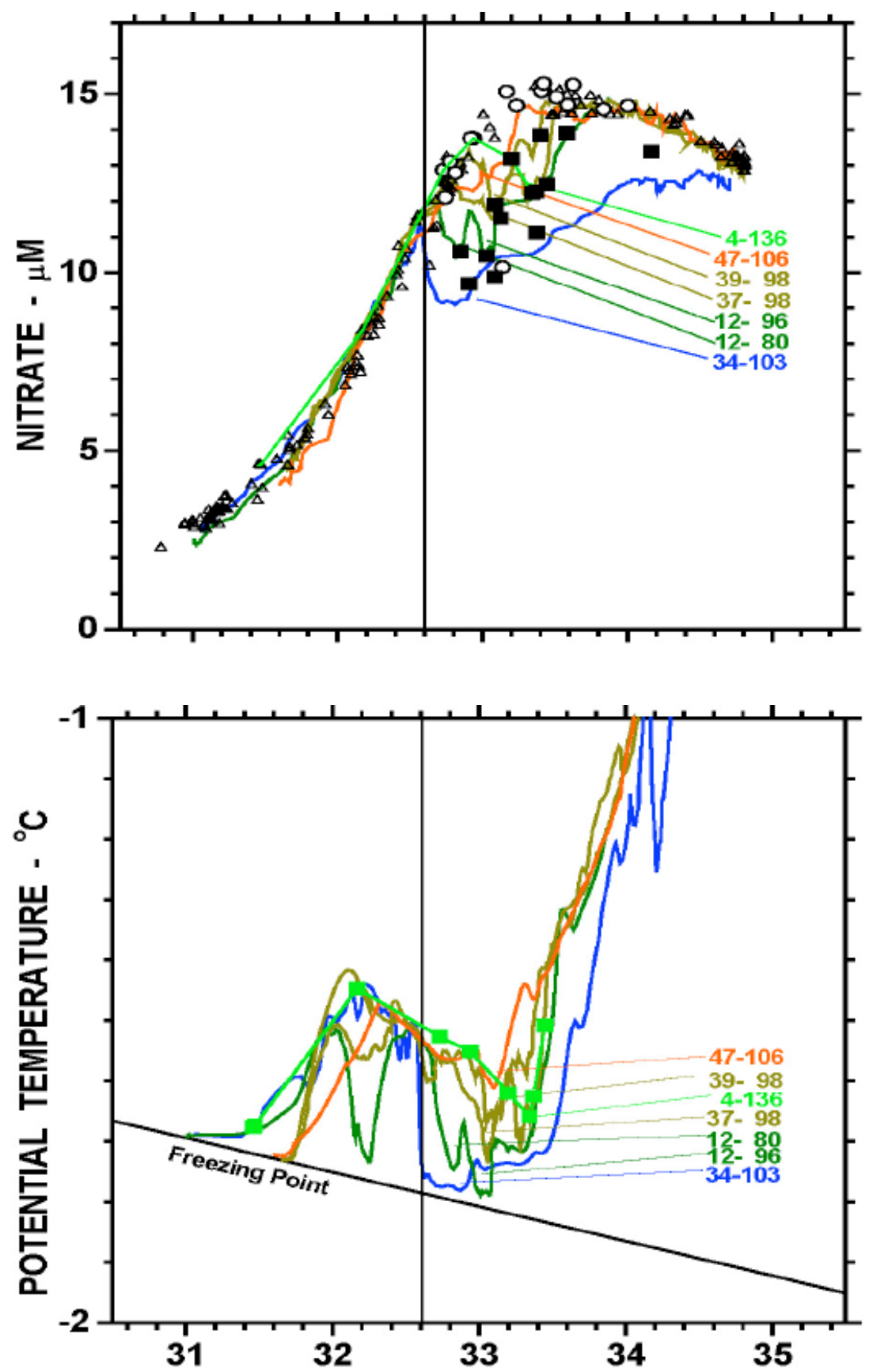

Fig. (4). TOP: Relationship of nitrate concentrations to salinity for all bottle samples. Most samples fell along a well-constrained relationship with salinity (open triangles). Occasional samples with anomalous low nitrate concentrations (darkened squares) were found in the salinity range of 32.6-34.2. Selected continuous profiles are displayed with the CTD cast number and pressure (dbar) of the denoted nitrate minima. Open squares represented anomalous silicate samples with normal nitrate concentrations. BOTTOM: Relationship of potential temperature to salinity for the same selected profiles. A vertical line at salinity 32.6 was for reference.

profile of CTD 12 differed considerably from the two water mass assemblies. At pressures greater than $70 \mathrm{dbar}$ and salinities above 32.6, salinities of this CTD cast increased rapidly while nitrate concentrations remained between 11-14 $\mu \mathrm{M}$ and temperatures plunged toward the freezing point. Thus, the temperature and salinity relationship shifted from the assembly A-E toward the freezing point assembly of FG. Below this depth, the properties migrated back toward the general relationship (A-E), converging with the general relationship at a salinity of 33.8 , a nitrate concentration of $14.8 \mu \mathrm{M}$, and a temperature of $-1.4^{\circ} \mathrm{C}$. We suggest that these deviations from the general trends represented instances where surface waters had been subjected to freezing and had sunk to the depth of the observed anomalies. As we describe dissolved silicate concentrations in the next paragraphs, we note here that these nitrate anomaly samples also had lowered silicate concentrations.

We found a restricted number of stations on nearly every transect which had these anomalous nitrate profiles. Major anomalies were found at CTD 47 (transect A), CTDs 37-39 (transect B), CTD 4 (transect C), CTD 12 (transect D), and at 
Table 2. Water Mass Identification Based on Three Dimensional Property Plots Using Potential Temperature, Salinity, and Nitrate or Silicate Concentration. Water Masses are: Atlantic Water (A), Lower Halocline Water (B), Middle Halocline Water (C), Upper Halocline Water (D), Chukchi Summer Water (E), Freezing Upper Halocline Water (F), Freezing Chukchi Summer Water (G), and Freezing Arctic Surface Water (H)

\begin{tabular}{|c|c|c|c|c|c|}
\hline Letter Name & Assembly \# & $\mathbf{T}_{\theta}^{\circ}{ }^{\circ} \mathbf{C}$ & Salinity & Nitrate $\mu \mathrm{M}$ & Silicate $\mu \mathrm{M}$ \\
\hline A & 1 & +0.63 & 34.85 & 13.0 & 8.0 \\
\hline $\mathrm{C}$ & 1 & -1.40 & 33.40 & 15.2 & 31.5 \\
\hline $\mathrm{D}$ & 1 & -1.55 & 33.10 & 14.5 & 30.0 \\
\hline $\mathrm{F}$ & 2 & -1.81 & 33.10 & 14.5 & 30.0 \\
\hline G & 2 & -1.75 & 32.10 & 7.2 & 16.0 \\
\hline $\mathrm{H}$ & 2 & -1.68 & 30.80 & 1.8 & 8.0 \\
\hline
\end{tabular}

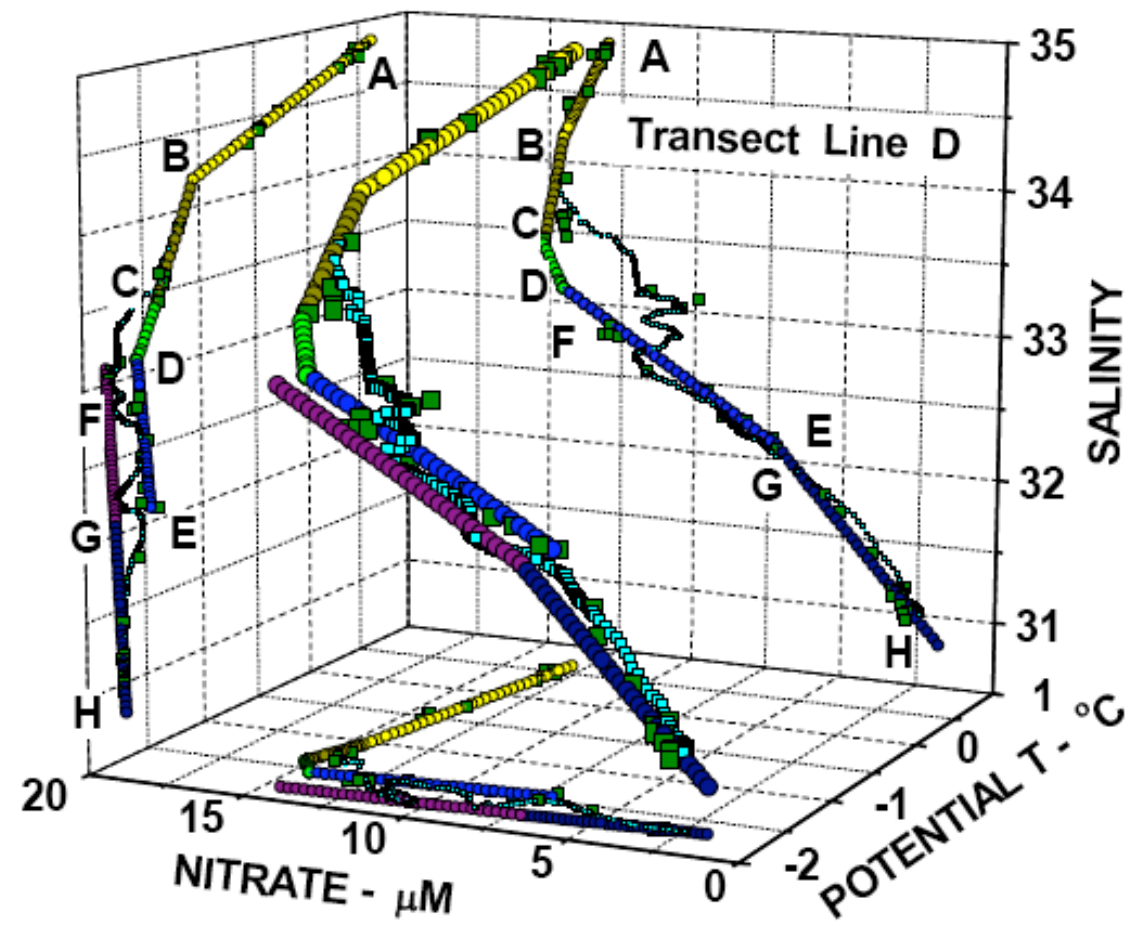

Fig. (5). Three-dimensional property plot of bottle data and one continuous profile from transect line D. The three-properties were potential temperature, nitrate concentration, and salinity. The three-dimensional structure was drawn with the larger symbols, while projections onto the three two-dimensional graphs were shown with smaller symbols. Lines with sequential circles represented mixing lines between the eight water masses designated by letters (A - H, Table 2). Dark green squares represented the bottle samples from all CTD casts on Transect Line D. One continuous profile (CTD 12, smaller light blue circles) clearly showed the anomalous mid-depth region in the salinity range of 32.633.8. The non-traditional orientation of the axes was employed so that the three-dimensional image and the three projections did not overlap.

all CTDs (32-36) on transect E. The nitrate-salinity relationship of the continuous profiles (Fig. 4 top) showed that these intrusions occurred over a broad depth zone, but that the main minima in nitrate concentration occurred at similar depths for most stations. On transect line $\mathrm{A}$, the nitrate minima at CTD 47 occurred between 80 and 106 dbar. Here, the reduction in nitrate concentration was relatively minor. The mimima found at sites to the west of line A occurred at the same depth (80-105 dbar) but the nitrate concentrations were lower. Also, the sites west of line A had greater range of depths that were influenced by the intrusions. The site with the largest intrusion was CTD 34 (transect E), where a broad depth span of anomalous nitrate concentrations began at a salinity and pressure of 32.5 and $100 \mathrm{dbar}$ and extended to the maximum pressure of 280 dbar. Also, the sites with the most intense anomalies along each transect (CTDs 34, $12,4,37$, and 47) were the stations next to the continental slope. Our conclusion was that this nitrate anomaly water had begun west of transect line E, where the intrusions were most intense, and portions of this water were advecting along the continental slope at a core depth of 80-106 m. 


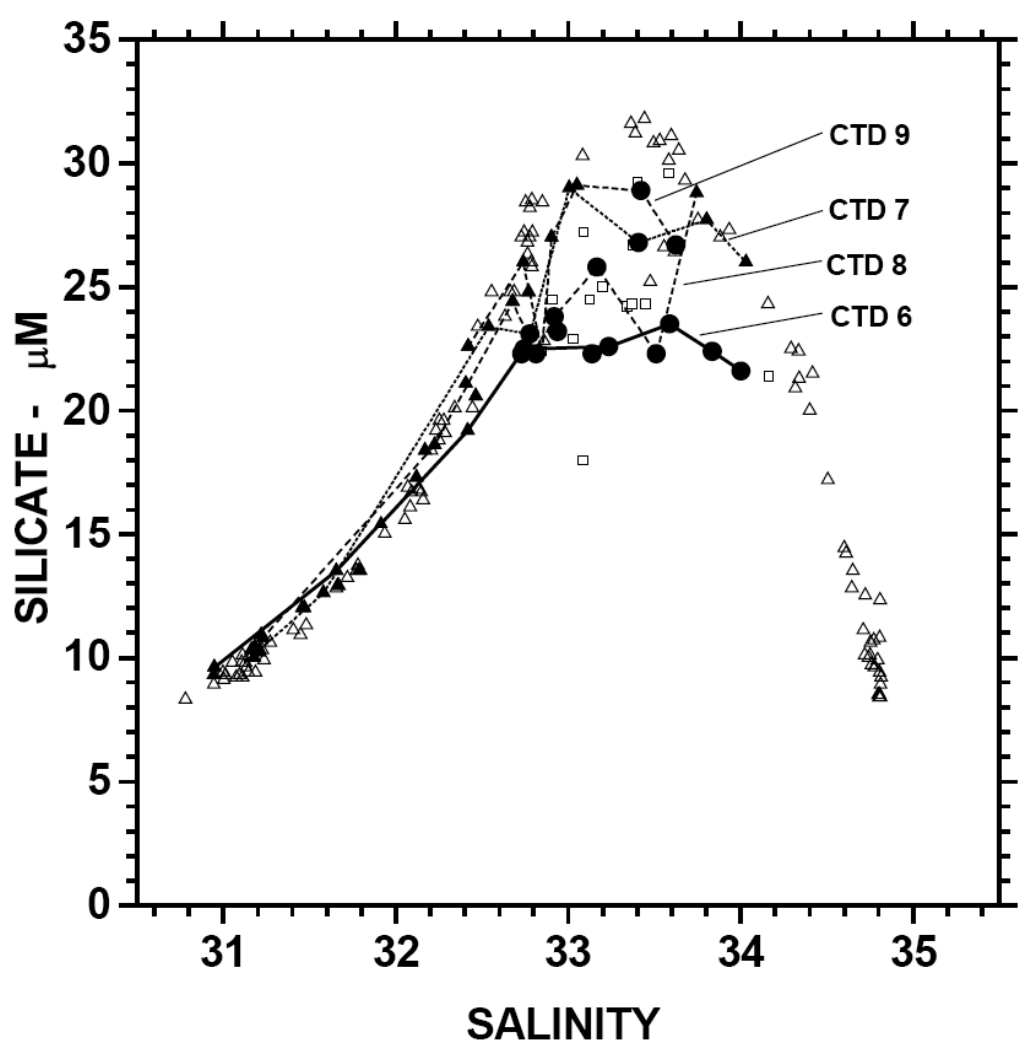

Fig. (6). Relationship of dissolved silicate concentrations to salinity for all bottle samples. Those that fell along the normal relationship of silicate to salinity were open triangles. Normal samples from CTDs 1-9 were darkened triangles. Samples with anomalous nitrate concentrations in Fig. (4) were open squares. Samples with anomalous low silicate concentrations were darkened circles. Lines connected bottles by increasing depth for casts CTD 6 (solid black line), CTD 7 (dotted line), and CTDs 8, 9 (dashed line).

\section{Dissolved Silicate}

Silicate concentrations generally were well correlated with salinity (Fig. 6). However, a second group of anomalous samples had lowered silicate concentrations relative to their salinity (Fig. 6). These 16 samples had silicate concentrations as low as $21.6 \mu \mathrm{M}$ relative to the expected concentrations of 25-33 $\mu \mathrm{M}$ from the sample's salinity. Also, these samples had nitrate concentrations that matched the typical nitrate-salinity relationships, so they appeared different from the nitrate anomaly samples that had both lowered nitrate and lowered silicate concentrations. This second group was found primarily along transect line $\mathrm{C}$. The station with the most extensive occurrence of these waters was CTD 6, just north of this transect's nitrate anomaly site (CTD 4). At CTD 6 , the silicate anomalies began at $101 \mathrm{dbar}$ and extended to the deepest bottle sample (176 dbar), and the silicate concentrations of all these bottle samples were remarkably similar, 21.6-23.5 $\mu \mathrm{M}$. Intrusions were also found at CTD 7-9 but with greater silicate concentrations and within more restricted depth ranges than at CTD 6. Finally, the shape of the silicate-salinity relationship at CTD 6 was similar to the shape of the strong nitrate-anomaly intrusions (e.g. CTD 34), in which nutrient concentration stayed moderately stable while salinities increased dramatically. Temperatures in these silicate anomaly waters decreased somewhat toward the freezing point but remained at least $0.15^{\circ} \mathrm{C}$ above it. This pattern suggested that these silicate anomaly waters were also formed by past deep convection, at sites likely removed from our study grid. Since the nutrient properties of this second group of anomalies differed from the nitrate anomaly samples, and since the volume of water containing this second type was much less, we inferred that this second water type might have been a remnant of a much earlier convection event.

\section{${ }^{18} \mathrm{O} /{ }^{16} \mathrm{O}$ Isotope Ratios}

The isotopic content of seawater has been used to evaluate the extent of fresh water loss from sea ice formation. This approach works because most fresh waters added to the ocean are isotopically light in ${ }^{18} \mathrm{O}$ relative to ${ }^{16} \mathrm{O}$ $\left(\delta^{18} \mathrm{O}\right.$ generally ranges from $-16 \%$ to $\left.-24 \%\right)$, whereas, most sea-ice is formed from seawaters with $\delta^{18} \mathrm{O}$ values of $0 \%$ to $4 \%[39,49,50]$. Also, the ice formation process fractionates isotopes only slightly, leaving the ice with $+2 \%$ greater $\delta^{18} \mathrm{O}$ than the source seawater. Thus, the ${ }^{18} \mathrm{O} /{ }^{16} \mathrm{O}$ isotopic content of seawater can be used to discriminate between dilution of seawater by rivers and precipitation versus the net impact of ice formation or melting.

For every nutrient sample we collected, a subsample of the water was used for the ${ }^{18} \mathrm{O} /{ }^{16} \mathrm{O}$ isotope determinations. We found that the $\delta^{18} \mathrm{O}$ values correlated directly with salinity (Fig. 7). The variability was relatively large, $+/-1 \%$, which impeded determination of detailed differences between waters. For example, we highlighted the $\delta^{18} \mathrm{O}$ values of the anomalous nitrate samples found in the shelfbreak jet. The salinities of these samples were restricted (Fig. 4), so that these samples appeared only on a small portion of the $\delta^{18} \mathrm{O}$ versus salinity graph. However, their variability in $\delta^{18} \mathrm{O}$ 


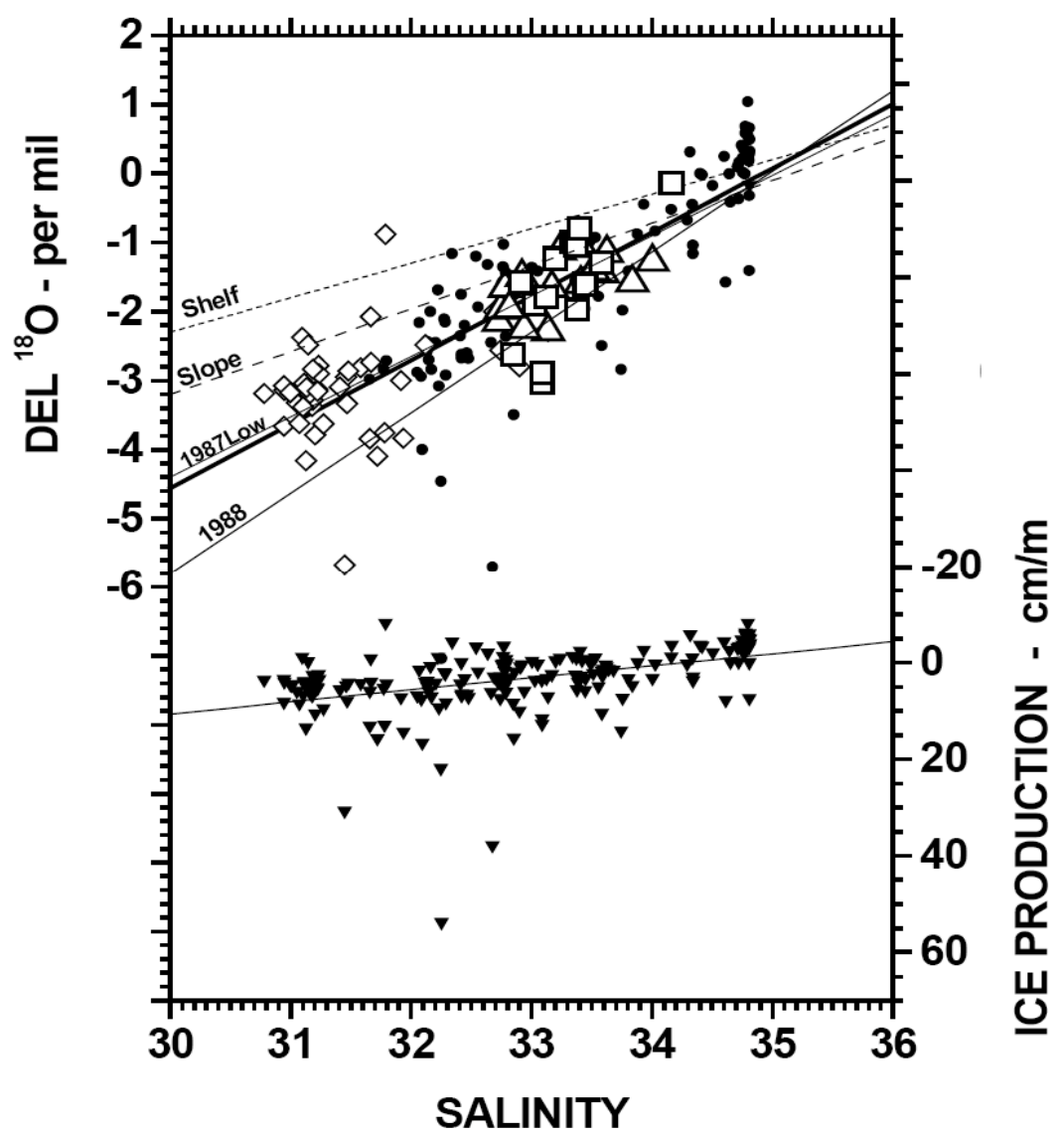

Fig. (7). Left axis: Relationship of $\delta^{18} \mathrm{O}$ isotope content to salinity. The regression of all samples (dark circles) was the thick dark line. Open squares represented the nitrate anomaly samples found in the shelfbreak jet. Open triangles represented the silicate anomaly samples. Open diamonds were the samples with temperatures within $0.01^{\circ} \mathrm{C}$ of the freezing point. Short dashed line was the condition of near-bottom samples from shallow summertime Chukchi Sea $(<100 \mathrm{~m}$ depth, [21] line marked Shelf). Longer dashed line was the regression for the summertime Chukchi continental slope (100-150 m, [21] line marked Slope). Thin solid lines represented the Beaufort Sea in 1988 (line marked 1988) and in spring 1987 for the lesser fractionated boundary (1987 Low). Right Axis: Ice production (cm of sea-ice thickness formed per $\mathrm{m}$ high column of sample seawater) for all samples (dark inverted triangles). The line is its regression onto salinity.

was about the same as the non-jet samples in the same salinity range. In like manner, both the anomalous silicate samples and samples which had temperatures within $0.01^{\circ} \mathrm{C}$ of the freezing point had a restricted range of salinities, but their variabilities in $\delta^{18} \mathrm{O}$ were similar in magnitude with the other samples. Also, no consistent geographic differences (east versus west or offshore versus onshore) were detected. The linear regression of $\delta^{18} \mathrm{O}(\%)$ onto salinity for all samples yielded $\delta^{18} \mathrm{O}=0.927 \times$ Salinity -32.4 , with $n=179$ and $\mathrm{r}^{2}=0.685$.

The oxygen isotope distribution versus salinity showed strong evidence of ice-formation, as is demonstrated by comparing it with other Arctic data sets. Extensive isotope data has been published for the summertime Chukchi Sea [21]. Samples from the northern Chukchi continental slope $(100-150 \mathrm{~m})$ matched those found in the central Arctic Ocean [51], suggesting that the summertime slope waters near our study site mimicked the general basin-wide trends. However, seventy five percent of our samples were more negative than these slope values, suggesting significant impact of ice formation. Interestingly, the summertime Chukchi samples at the bottom of shallow stations $(<100 \mathrm{~m}$ depth) had ${ }^{18} \mathrm{O}$ contents averaging about $1 \%$ heavier than those at depth on the northern Chukchi continental slope [21]
(Fig. 7). Since Arctic fresh waters generally are more negative $(-16$ to $-24 \%)$ than seawater, this relationship between Chukchi surface waters and slope waters is opposite that expected trend. In addition, the fresh water components of the summer Chukchi data had widely different isotopic contents [21]. Surface waters had a fresh-water end member of $-8.9 \%$, Chukchi bottom waters $(<100 \mathrm{~m}$ depth) had their fresh water end member of $-17.3 \%$, and the fresh water end member for Chukchi slope waters (100-150 m) was $-21.8 \%$. The widely varying fresh water isotopic content across the Chukchi may contribute to the high variability $(+/-1 \%)$ seen in our data. Nevertheless, from our regression of ${ }^{18} \mathrm{O}$ content onto salinity, the freshwater component in our study had a $\delta^{18} \mathrm{O}$ content of $-32.4 \%$, a value much more negative than either the literature values of Arctic fresh waters or the summertime Chukchi fresh end members. Extensive isotopic measurements were made in the Beaufort Sea offshore of the Mackenzie River Delta in late March of 1986, 1987, and 1988 [52]. Mixing lines, labeled 1987-Low and 1988, delineate the spread in several regression lines from that study, and all these regressions indicated significant fractionation due to extensive ice formation. Many of our samples match $\delta^{18} \mathrm{O}$ values of the results of the Mackenzie study. 
The oxygen isotopic content and salinity can be considered to result from mixing between a freshwater (meteoric) source, Atlantic water, and ice melt or formation. Consequently, the relative fractions of meteoric, Atlantic, and ice water were calculated following Ostlund and Hut [39];

$f_{a}+f_{m}+f_{i}=1$,

$f_{a} S_{a}+f_{m} S_{m}+f_{i} S_{i}=S_{s}$,

$$
\mathrm{f}_{\mathrm{a}} \delta_{\mathrm{a}}+\mathrm{f}_{\mathrm{m}} \delta_{\mathrm{m}}+\mathrm{f}_{\mathrm{i}} \delta_{\mathrm{i}}=\delta_{\mathrm{s}}
$$

The three fractions of the mixture (Atlantic Water, meteoric water, and ice) are given by $f_{a}, f_{m}$, and $f_{i}$. Ostlund and Hut [39] defined these fractions relative to a kilogram of seawater, so the actual units of any fraction, $f_{x}$, were $\mathrm{kg}_{\mathrm{x}} / \mathrm{kg}_{\text {sample. }}$. For example, for the sea-ice fraction $\left(\mathrm{f}_{\mathrm{i}}\right), \mathrm{kg}_{\mathrm{i}}$ was the kilograms of seawater added or removed as sea-ice, and $\mathrm{kg}_{\text {sample }}$ was the mass of total sample water. The salinities of Atlantic Water $\left(\mathrm{S}_{\mathrm{a}}\right)$, meteoric water $\left(\mathrm{S}_{\mathrm{m}}\right)$, and sea-ice $\left(\mathrm{S}_{\mathrm{i}}\right)$

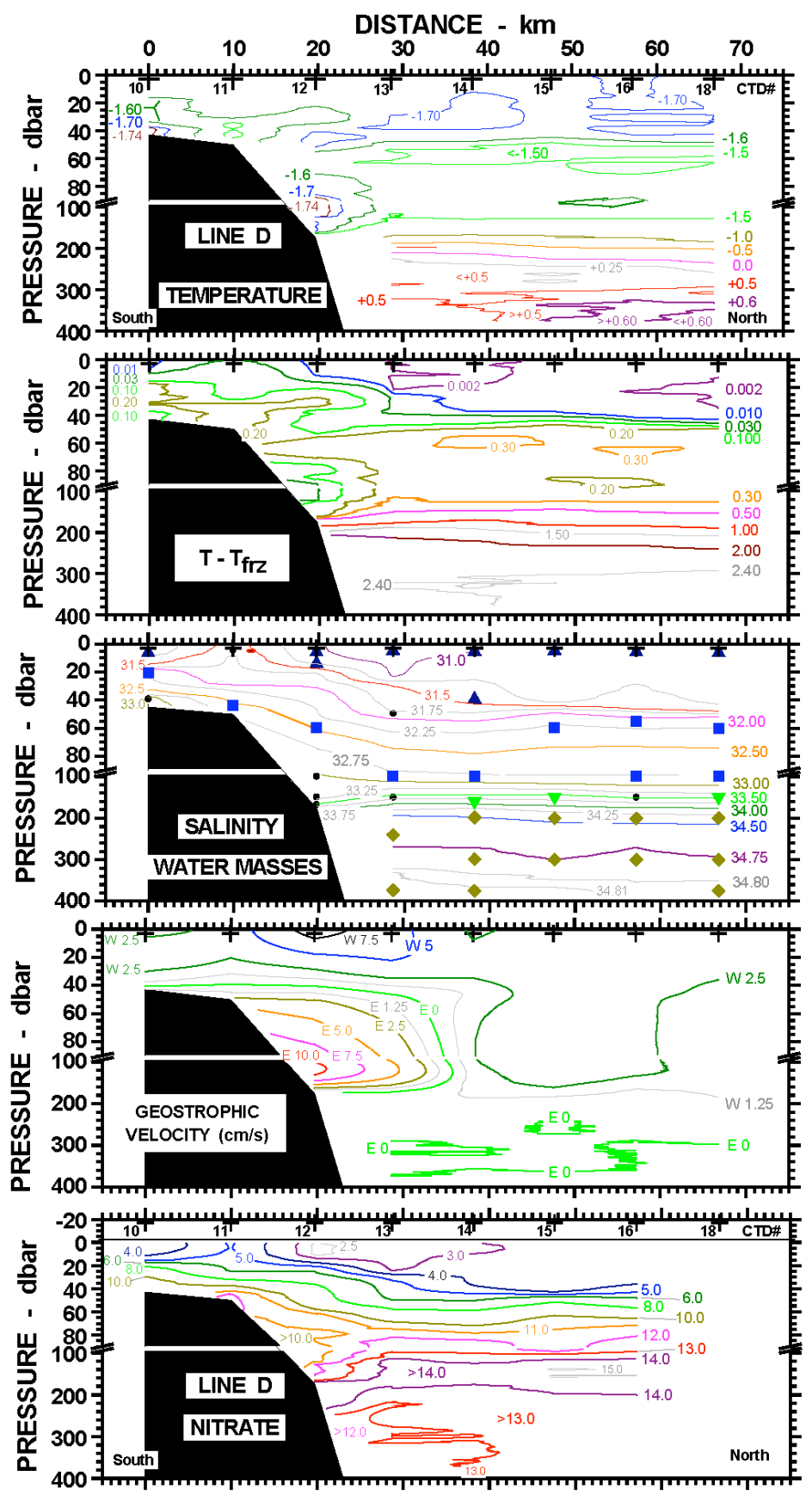

Fig. (8). Vertical sections of temperature, temperature above the freezing point $\left(T-T_{\text {frz }}\right)$, salinity, geostrophic velocity (cm/s), and nitrate concentration $(\mu \mathrm{M})$ along transect line D. On the salinity section, water samples were identified as to their water mass by colored symbols at their station and depth. Black dots represented water samples not corresponding to the any water type. Dark blue upward triangles represented samples along the mixing line between Arctic Surface Water and Upper Halocline Water. Blue squares represented those along the Upper Halocline - Middle Halocline mixing line. Green inverted triangles represented those along the Middle Halocline - Lower Halocline mixing line. Dark yellow diamonds represented those along the mixing line between the Lower Halocline Water and Atlantic Water. Geostrophic velocities are designated as flowing toward the northwest $(\mathrm{W})$ or southeast $(\mathrm{E})$. 
were $34.85,0$, and 5 , and the isotopic contents of Atlantic Water $\left(\delta_{\mathrm{a}}\right)$, meteoric water $\left(\delta_{\mathrm{m}}\right)$, and sea-ice $\left(\delta_{\mathrm{i}}\right)$ were $-0.3 \%$, $-21.0 \%$, and $\delta_{\mathrm{s}}+2.0 \%$. The salinity and isotopic content of the sample being partitioned were $\mathrm{S}_{\mathrm{s}}$ and $\delta_{\mathrm{s}}$. By solving these three equations simultaneously, the fractional proportion of these three waters was determined in each isotopic sample. The fractional ice content can be converted to the thickness of sea-ice formation or melt, $t_{i}$, in units of $\mathrm{cm}$ of ice thickness per $m$ deep column of seawater, using equation 5 . In this equation, $\rho_{\text {sample }}$ was the density of the original seawater sample, $\rho_{\text {imsw }}$ was the density of sea water produced or consumed in the melting or freezing of the sea-ice, and $\rho_{\text {ice }}$ was the density of solid sea-ice [52]. The factor, $\mathrm{k}$, is $100 \mathrm{~cm}$ $\mathrm{m}^{-1}$. The factor, $\rho_{\mathrm{imsw}}$, being in both the numerator and denominator, dropped out of the equation. Also the units of conversion included the horizontal surface area $\left(\mathrm{m}^{2}\right)$ in both the numerator and denominator and canceled from the result. Considering the average density of sea water in our study area approximated $1023 \mathrm{~kg} \mathrm{~m}^{-3}$ and the density of solid sea ice was $900 \mathrm{~kg} \mathrm{~m}^{-3}$, the multiplier, $\left(\rho_{\text {sample }} / \rho_{\text {ice }}\right) \times \mathrm{k}$, was $113.67 \mathrm{~cm} \mathrm{~m}^{-1}$. Including this multiplier, the regression of ice production on salinity was, $\mathrm{t}_{\mathrm{i}}=2.495 \times \mathrm{S}_{\mathrm{i}}+85.471$ (Fig. 7), and for waters of salinity 31 , this equation yielded $8.1 \mathrm{~cm}$ of sea-ice growth from a meter high column of original sample water. The slope of the regression indicated that waters of greater salinity were less impacted by sea-ice formation (Fig. 7). Similar calculations showed that in 1988 in the Beaufort Sea, the average sea-ice growth was $11-17 \mathrm{~cm}$ of ice $\mathrm{m}^{-1}$ [52]; while in the central Arctic it had averaged 3-6 cm of ice $\mathrm{m}^{-1}[51]$.

$\mathrm{t}_{\mathrm{i}}=\mathrm{f}_{\mathrm{i}} \times\left(\rho_{\text {sample }} / \rho_{\text {imsw }}\right) \times\left(\rho_{\text {imsw }} / \rho_{\text {ice }}\right) \times \mathrm{k}$,

\section{Vertical Sections}

Vertical sections were presented for transect line D (Fig. 8). The major physical features found in the section included first, a patch of low salinity water at the surface at CTD 13. The southern edge of this patch separated northern waters with temperatures within $0.01^{\circ} \mathrm{C}$ of the freezing point from slightly warmer surface waters over the shelf and upper slope. Nitrate concentrations were also lowest $(2.5 \mu \mathrm{M})$ within the core of this patch. Here, we designate this patch as
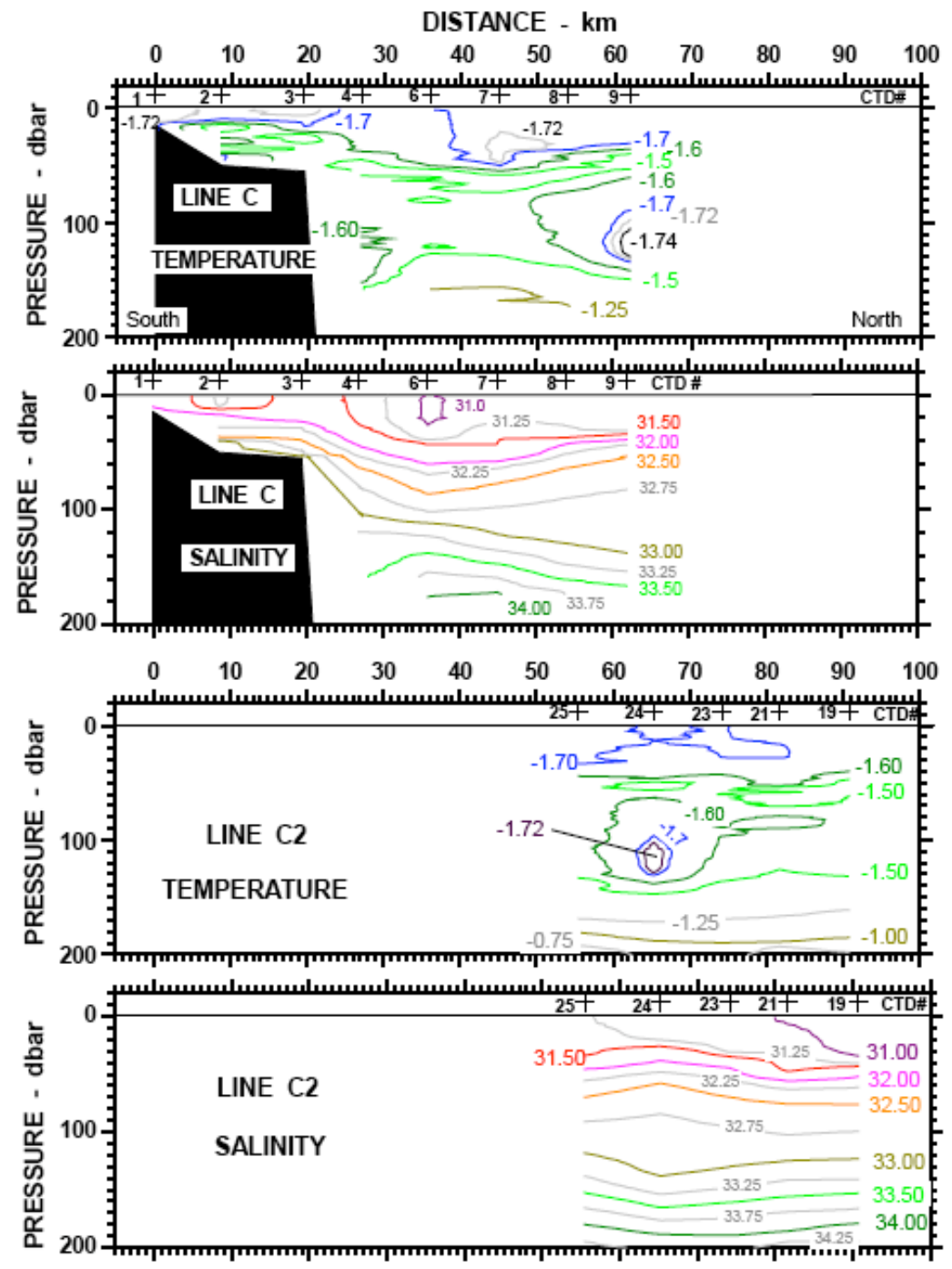

Fig. (9). Vertical sections along transect $\mathrm{C}$ and $\mathrm{C} 2$. Top two panels are temperature and salinity along transect $\mathrm{C}$. Bottom two panels are temperature and salinity along transect $\mathrm{C} 2$. A small eddy with core temperatures of $-1.74^{\circ} \mathrm{C}$ and doming isohaline lines was observed on both transects at the distance of about $65 \mathrm{~km}$ from CTD 1 . 
a shallow surface eddy, and the evidence will be presented below. Secondly, upwelling of salinity and nitrate was clearly visible in the range of 20-100 dbar and within 20-30 $\mathrm{km}$ of the shelf edge. This uplift in isohaline contours coincided with the existence of the Beaufort shelf break current, outlined in the section of geostrophic velocities. The core of this shelfbreak flow occurred at about 100 dbar next to the seafloor and had maximum velocities to the southeast (perpendicular to the section) of about $10 \mathrm{~cm} \mathrm{~s}^{-1}$. The current was about $20 \mathrm{~km}$ wide, ending at between CTD 13 and 14 where the slow westward gyre flow dominated. Eastward flow of this slope current occurred as shallow as $40 \mathrm{dbar}$ at the inshore stations. Within the core of the shelfbreak current, nitrate concentrations were at a minimum relative to either the shallower or deeper strata, as mentioned above in the section about anomalous nitrate concentrations. Temperatures in this core were below $-1.74^{\circ} \mathrm{C}$. Thus, the core of the shelfbreak current was carrying the anomalous nitrate waters. The vertical sections for every transect line demonstrated this shelfbreak current.

In addition to a surface eddy found in Line D (Fig. 8), a deeper eddy was observed along transect line C (Fig. 9). In the first transect occupied on the cruise, a bolus of cold water was observed centered at about $120 \mathrm{~m}$ at CTD 9 on April 3, $62 \mathrm{~km}$ offshore of the inshore station, CTD 1 (Fig. 9). Core temperatures were below $-1.74^{\circ} \mathrm{C}$, but the surrounding waters were between -1.5 and $-1.6^{\circ} \mathrm{C}$. In addition, salinity contours centered around the salinity of 32.8 showed a widening distance between isohalines as the cold core was approached (Fig. 9). The offshore portion of the section was reoccupied on April 9 in transect line C2. Again, the bolus of water of identical properties was observed centered at about the same location (120 m, CTD 24, Fig. 9). The continuous nitrate profiles at CTD 24 showed that the core of this water had normal nitrate to salinity relationships. These data indicated an anticyclonic eddy of approximately $20 \mathrm{~km}$ diameter. Importantly, the cold water core of the eddy did not shift location between April 3 and April 9. This implies that the mesoscale system was relatively motionless, even though water was advecting through the region.

\section{The Mesoscale Distribution of Salinity}

The vertical sections from all transects (Fig. 8) indicated that between about $40 \mathrm{~m}$ and $150 \mathrm{~m}$, the isohalines contour lines became deeper with distance offshore. To better study this, we developed gridded maps of salinity distributions at $10 \mathrm{~m}, 50 \mathrm{~m}, 110 \mathrm{~m}$, and $260 \mathrm{~m}$ depth (Fig. 10) by locating the salinity at the respective depths for each CTD profile and then employing objective interpolation and block kriging. These salinity distributions were used as indicators of the impact of the mesoscale physical field on water properties.

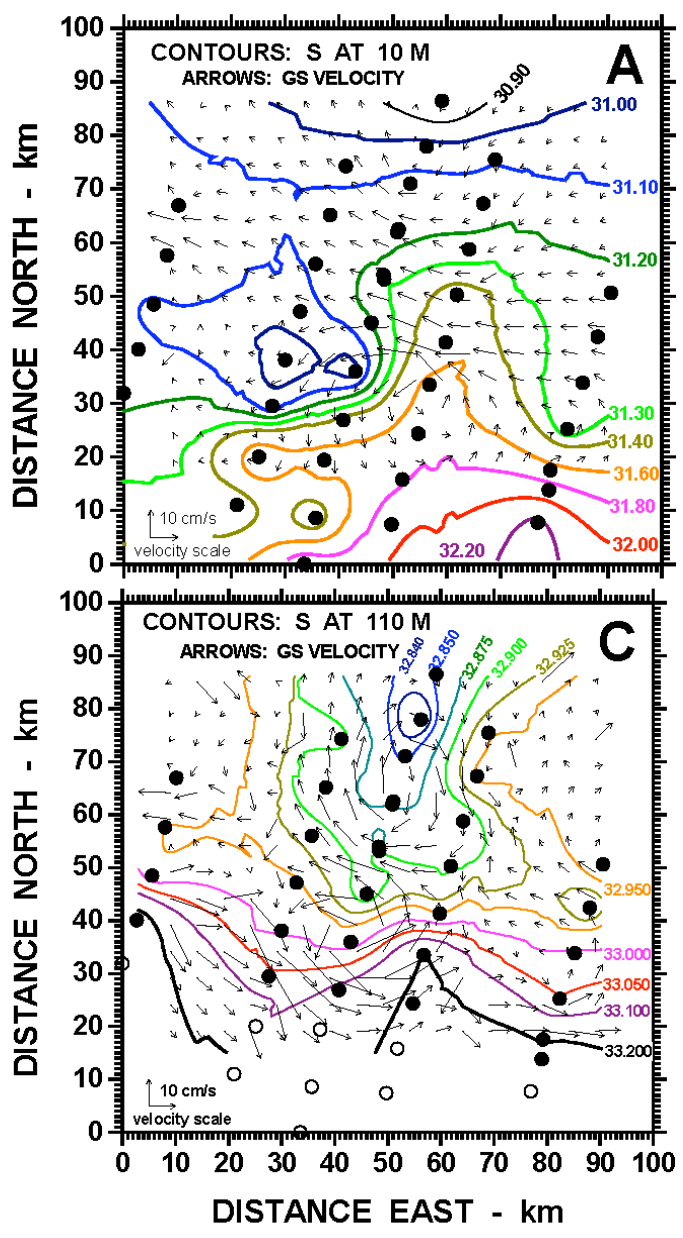

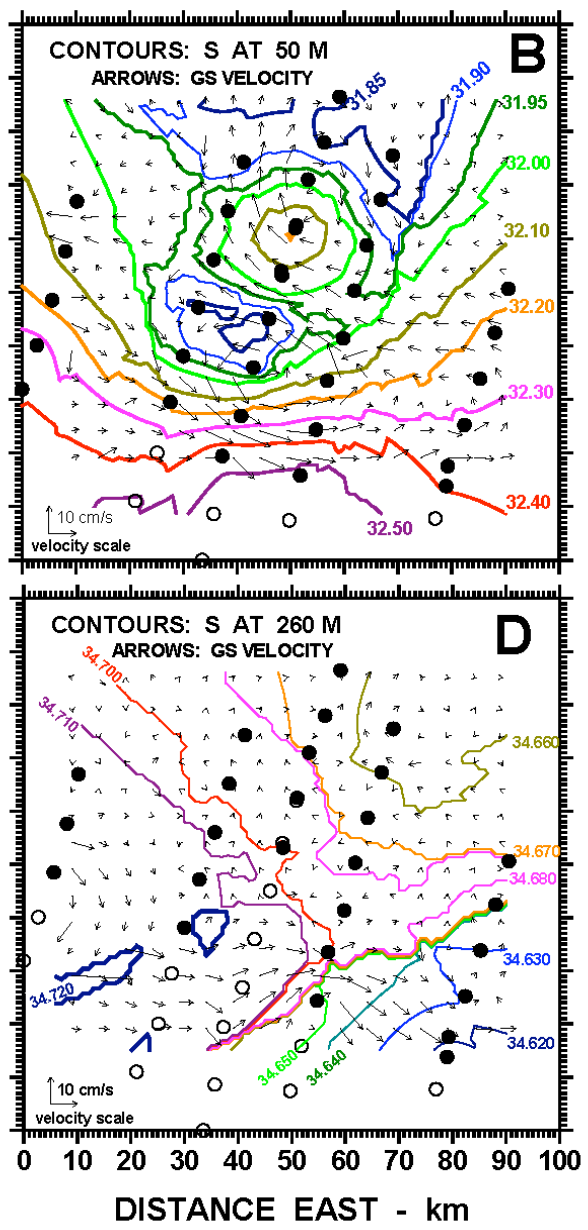

Fig. (10). Maps of salinity and geostrophic velocities at selected fixed depths of $10 \mathrm{~m} \mathrm{(A),} 50 \mathrm{~m}(\mathbf{B}), 110 \mathrm{~m}(\mathbf{C})$ and $260 \mathrm{~m}$ (D). The salinity of each contour line is listed. Velocity scales are in the bottom right corner in each panel. Solid circles indicated the stations deep enough to be used in each salinity map, while open circles represented excluded shallow stations. 
Looking first at the $10 \mathrm{~m}$ distribution, lowest salinities were found at the furthest offshore sites where salinities were less than 31.0 (Fig. 10A). A minima in the salinity field $(<31.00)$ also occurred over CTDs 6 and 13, clearly designating the patch of low salinity water noted in the vertical section of Line D as the center of a shallow near-shore eddy. Highest salinities $(>32.2)$ were found in the southeast corner of the grid along transect line A at the inshore site (CTD 48). The band of moderate salinities (31.40-31.80) extended westward from CTDs 48 and 49 slightly past line D (CTD 11) along the shelf edge. Assuming that this band represented the nearsurface expression of the underlying shelf-edge upwelling, upwelling intensity would appear to be greater along transect lines A and B at this depth. Most interestingly, this band of moderate salinities also extended offshore along transect line B. The plume extended as far as CTD 28 on Line B, indicated by the salinity contour line of 31.2 .

The map of salinity at $50 \mathrm{~m}$ depth showed that the highest salinities $(>32.5)$ were located inshore on the center transects (Lines B, C, and D, Fig. 10B). Slightly lower salinities were found inshore on the two outside transects (A and E). The high salinities found inshore on transect line $\mathrm{C}$ dropped quickly with distance offshore to minimum values $(<31.85)$ at CTDs 6 and 7, this minimum defining the core of the shallow eddy. Further offshore on line $\mathrm{C}$, the salinity at $50 \mathrm{~m}$ increased to intermediate values $(>32.1)$ in the central dome of the deeper eddy (CTD 9 and 24), but then decreased to $<31.85$ in the most offshore sites. The decrease in salinity at $50 \mathrm{~m}$ with distance offshore was less severe on the outside transects (lines A and E), so that salinities on these transects were greater than those found on the central transects at the same distance north.

The salinity map at $110 \mathrm{~m}$ had many similarities. In a manner similar to the $10 \mathrm{~m}$ distribution, highest salinities (>33.2) occurred along the shelf break between lines A and $\mathrm{B}$ and as a plume extending slightly offshore on Line B (CTDs 39 and 37). Also, these high salinities were found at the shelf break site (CTD 35) on line E. The lowest salinities occurred as a plume of $<32.925 \mathrm{~S}$ water extending from the northern boundary into the center of the grid along the three center transects, B, C, and D (Fig. 10C). The center of this plume contained the deeper offshore eddy with salinities of $<32.875$. Interestingly, this plume suggests that the deeper offshore eddy on transect line $\mathrm{C}$ may be connected to lower salinity waters further offshore. At $260 \mathrm{~m}$ depth (Fig. 10D), salinity across the sampling grid varied very little $(<0.08 \mathrm{~S})$.

\section{Mesoscale Distributions of Geostrophic Currents}

To better examine the mesoscale physical field, we developed geostrophic velocity distributions at 10, 50, 110, and $260 \mathrm{~m}$ depths. From the dynamic heights at all CTD stations, the gridded fields of dynamic height were computed based on objective interpolation and block kriging. Geostrophic velocities were calculated from the horizontal gradients at each level as well as at the reference level (360 $\mathrm{m})$. Then, at each grid point, the vector velocities at $360 \mathrm{~m}$ were subtracted from the vector velocities at the shallower layers. Note that the interpolation algorithm produced a statistically valid rectangular domain, with axes of distance east versus distance north, which covered the stations having data at the particular depth. Geostrophic velocities corrected for the reference depth were only computed for the smaller domain of the $360 \mathrm{~m}$ depth. The dominant flow at $10 \mathrm{~m}$ depth (Fig. 10A) was a westward flowing current found at $50-60 \mathrm{~km}$ north of the southern most CTD site. Velocities within the main flow were between $5-10 \mathrm{~cm} / \mathrm{s}$. At the two eddies, the anticipated rotational flow around each eddy's center was lacking, apparently because the westward flowing surface current overpowered the eddy circulation. Nevertheless, the two eddies acted to redirect a portion of the westward flow. The deeper offshore eddy at CTD 24-25 (line C) shifted some of the westward flow to the northwest on transect line D, while the shallow eddy at CTD 6 (line D) redirected flow to the south along transect line C. This southward flow from CTD 6 resulted in a weak onshore flow of water across the shelf between transect lines B and D. Weak offshore flow across the shelf occurred between transect lines A and B. At $50 \mathrm{~m}$ depth, the geostrophic velocity map showed two major flows (Fig. 10B). The shelfbreak region had the Beaufort shelfbreak current flowing to the east at $5-15 \mathrm{~cm} / \mathrm{s}$. At about $50-70 \mathrm{~km}$ north of the southern station, a weakened westward flow $(<10 \mathrm{~cm} / \mathrm{s})$ was strongly affected by the two eddies. At this depth, the shallow eddy at CTD 6 (Line D) had a strong counterclockwise flow $(>10 \mathrm{~cm} / \mathrm{s})$ closely aligned with the salinity minima at the eddy's core. The deeper eddy (CTD 24-25 Line C) had a strong clockwise flow around the core salinity maximum with some velocities exceeding $10 \mathrm{~cm} / \mathrm{s}$. At $110 \mathrm{~m}$ depth, the primary flow was the Beaufort shelf break current with velocities exceeding $20 \mathrm{~cm} / \mathrm{s}$ to the east (Fig. 10C). Both eddies were clearly visible with strong counterclockwise flow around the shallow eddy center (CTD 6 ) and strong clockwise flow around the deeper offshore eddy (CTD 24-25). At $260 \mathrm{~m}$ depth, the flows were markedly reduced except in the eastward flow below the Beaufort shelfbreak current where velocities averaged 5-15 $\mathrm{cm} / \mathrm{s}$ (Fig. 10D).

\section{The Mesoscale Distribution of Nitrate}

We examined the distribution of nitrate concentrations in the surface waters and their relationship to the salinity distributions. The average concentration of nitrate in the upper $40 \mathrm{~m}$, determined by integration of the continuous profiles, ranged between 2.09 and $6.14 \mu \mathrm{M}$. When these average nitrate concentrations were mapped relative the salinity field at $50 \mathrm{~m}$, a close correspondence was seen (Fig. 11 top). Highest average nitrate concentrations $(>6 \mu \mathrm{M})$ cooccurred in areas where the $50 \mathrm{~m}$ salinities were greatest (salinities >32.4). Intermediate values of average nitrate concentrations $>4 \mu \mathrm{M}$ were found where salinities were greater than 32.0, including the dome of the strong clockwise eddy. Lowest average nitrate concentrations were found at the furthest stations offshore. A statistically significant regression was found between these two parameters, nitrate $=$ $3.22 \mathrm{x}$ salinity $-99.32, \mathrm{n}=34, \mathrm{r}^{2}=0.60$. The regression slope was significantly different from 0 ( $\mathrm{P}>0.01$, Student's $\mathrm{T}$ test). This regression suggested that the uplift in higher salinity waters, caused by the mesoscale physical field, had a strong relationship to higher nutrient concentrations in the upper 40 $m$ of the water column.

A second trend was also suggested in the map of $0-40 \mathrm{~m}$ nutrients (Fig. 11 top), this trend being that a greater propor- 

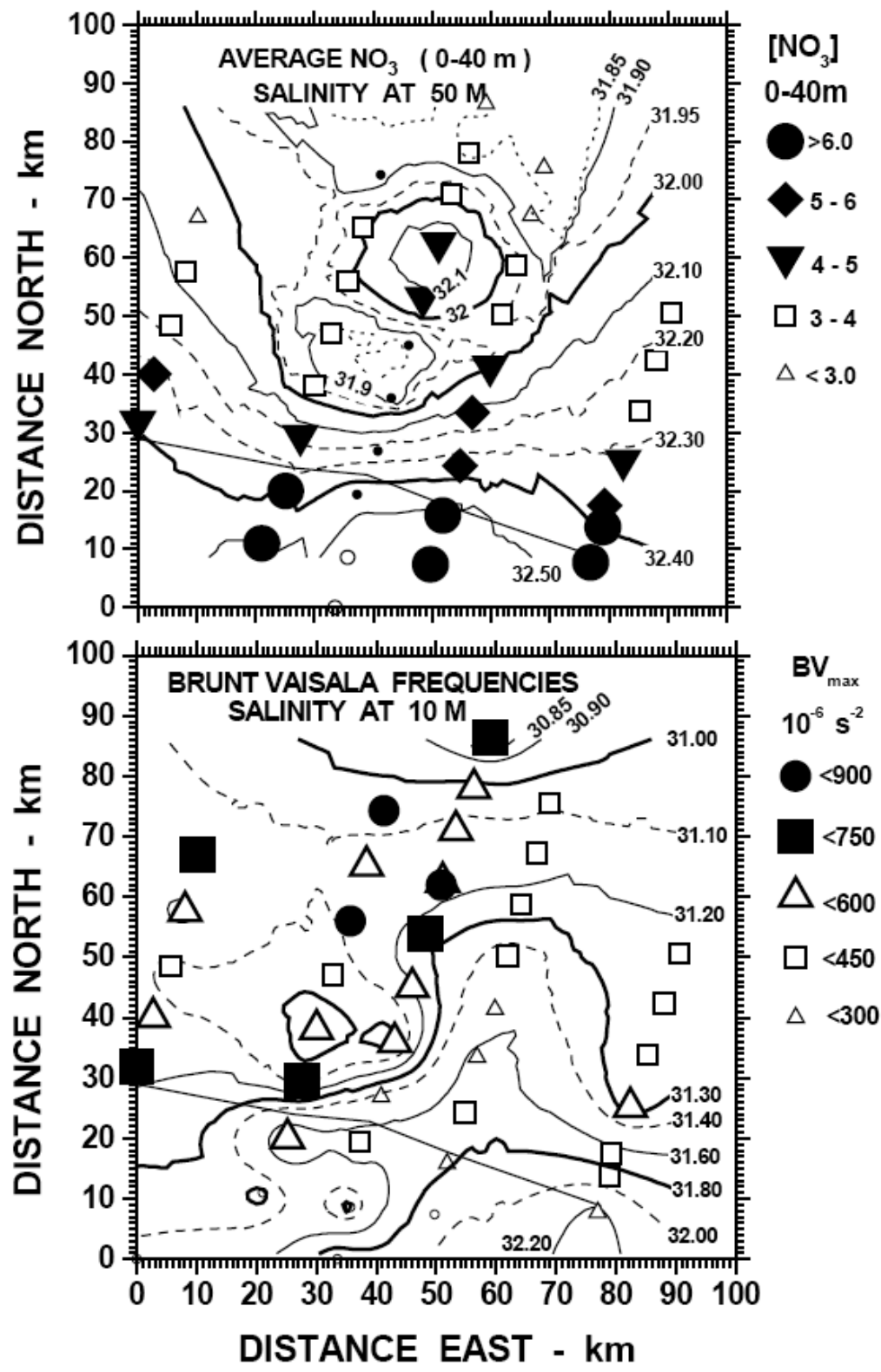

Fig. (11). TOP: Map of average nitrate concentration in the upper $40 \mathrm{~m}$ of water and salinity at $50 \mathrm{~m}$. Isohaline contour lines were marked with their salinity. Closed black dots were stations deeper than $50 \mathrm{~m}$ but lacking the continuous nitrate profiles. BOTTOM: Map of maximum Brunt Vaisala frequency in the primary pycnocline and salinity at $10 \mathrm{~m}$. Average nitrate concentrations and Brunt Vaisala frequencies were binned, with the symbols and scales at the right of each graph. Open black circles represented stations not used in the evaluations. Straight black lines indicated the position of the $100 \mathrm{~m}$ bathymetric contour.

tion of stations on the eastern two transects had high nitrate concentrations in comparison with the proportion of high nitrate sites found on the western transects. Considering just the sites within $30 \mathrm{~km}$ of the shelf break, 9 out of 10 sites on the eastern transects (lines A and B) had average nitrate concentrations of $4 \mu \mathrm{M}$ or greater. While on the western transects (lines D, and E), only 5 sites out of 9 within $30 \mathrm{~km}$ of the shelf break had these higher nitrate concentrations. Using the non-parametric Mann-Whitney U ranking test [53], the eastern region had significantly more high-nitrate sites near the shelf break than did the western transects $(\mathrm{P}>0.01)$. Thus, the physical processes promoting increased nitrate concentrations in the surface waters appeared to be more intense on the eastern transects.

\section{The Primary Pycnocline}

Since nitrate concentrations were closely correlated with salinity, the high average nitrate concentrations in the waters above the higher $50 \mathrm{~m}$ salinities could have been simply the result of the general uplift of the salinity contour lines due to the mesoscale physical field. However, there could be a more dynamic interpretation, in that the primary pycnocline, separating the low-nutrient surface waters and the deeper richer waters, could have varied in both its stability and its depth of occurrence in a manner related to the mesoscale eddy field. We examined this by calculating the Brunt Vaisala frequency $\left(\mathrm{N}^{2}\right)$ as a measure of the strength of the density stratification, the maximum frequency in each smoothed profile was accepted as the primary pycnocline 
and its core depth and core salinity were noted. The maximum frequency varied by 4.7 fold over a range between $178-836 \times 10^{-6} \mathrm{~s}^{-2}$. However, the strength of the pycnocline showed no relationship to the salinity found at $50 \mathrm{~m}$ depth (not shown). Instead, the distribution of the Brunt Vaisala frequency across the sampling grid indicated that more of the larger frequencies were found on the western side of the sampling grid (Fig. 11 bottom). On the western side with 30 CTD casts in Lines C, C2, D and E, the average frequency for all casts was $546 \times 10^{-6} \mathrm{~s}^{-2}$ (standard deviation of $+/-175 \mathrm{x}$ $\left.10^{-6} \mathrm{~s}^{-2}\right)$. The eastern two transect lines with $18 \mathrm{CTD}$ casts had an average of $363 \times 10^{-6} \mathrm{~cm}^{-2}$ (with a standard deviation of $80 \times 10^{-6} \mathrm{~s}^{-2}$ ), representing a pycnocline $66 \%$ as strong as found on the western transect lines. The difference between these two groups was statistically significant $(\mathrm{P}>0.01$, Students T test).

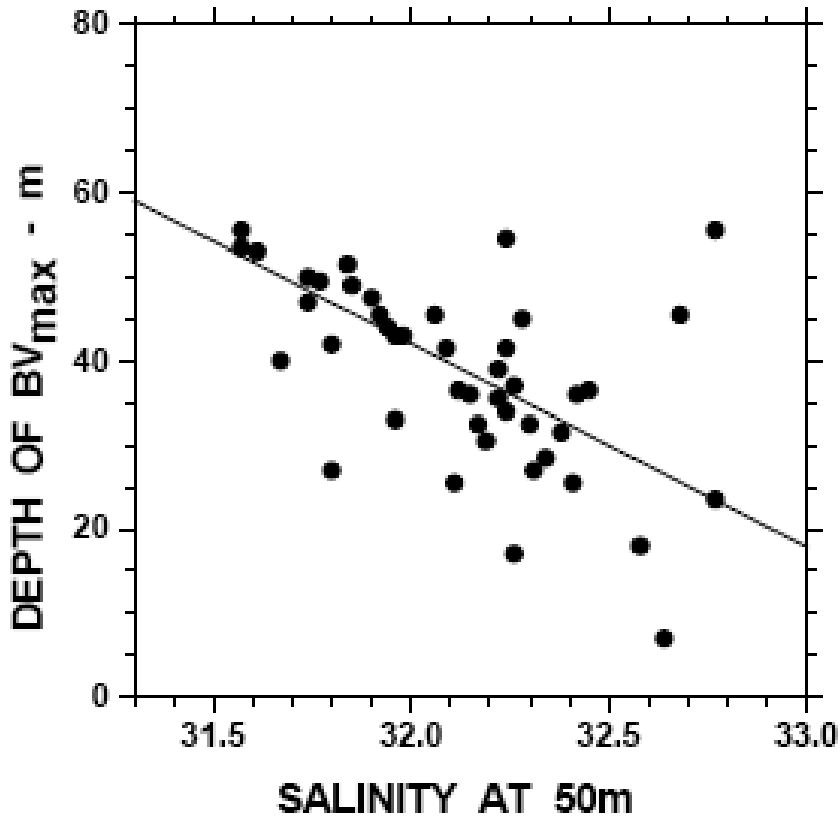

Fig. (12). Central depth of the pycnocline versus salinity at $50 \mathrm{~m}$. The line was the linear regression, $\mathrm{Z}_{\mathrm{BV} \max }=-23.94 \times \mathrm{S}+806.89$. The slope was statistically significant $(\mathrm{P}>0.01$, Student's $\mathrm{T}$ test $)$.

We also examined whether the vertical location of the pycnocline varied across the grid. At stations deeper than 50 $\mathrm{m}$, the pycnocline depth varied between 7 and $58 \mathrm{~m}$. By regressing the depth of the pycnocline center against the salinity at $50 \mathrm{~m}$, a strong inverse relationship was found (Fig. 12), where the average pycnocline depth varied between 21.6 and $52.6 \mathrm{~m}$ for $50 \mathrm{~m}$ salinities of 32.8 and 31.5 respectively. Consequently, where the salinity at $50 \mathrm{~m}$ was fresher, the pycnocline depth was deeper. In addition, this regression indicated that where the isohalines had been upwelled, the main pycnocline was much shallower. As a consequence, an additional effect of the mesoscale field was that the pycnocline moved to a shallower depth, one which was within the summertime euphotic zone, in association with the upwelling.

The lack of a strong relationship between the strength of the pycnocline (the value of the maximum Brunt Vaisala frequency) and the salinity at $50 \mathrm{~m}$ suggested that other factors determined the stability of the pycnocline. We examined whether the salinity in the surface waters could have been influential. The Brunt Vaisala frequencies were regressed against the salinities at $10 \mathrm{~m}$ depth, and a strong relationship was found (Fig. 13). The regression indicated that the pycnocline strength decreased with greater surface salinities. In equation 1 , the Brunt Vaisala frequency is directly proportional to the vertical gradient in density. Since salinity is the primary determinant of density, introduction of more saline water in the surface while maintaining the existing subsurface salinity distribution would decrease the resulting Brunt Vaisala frequencies. The map of the $10 \mathrm{~m}$ salinity distribution, plotted with the distribution of Brunt Vaisala frequencies (Fig. 11 bottom), showed that none of the higher Brunt Vaisala frequencies occurred in the areas where moderate $10 \mathrm{~m}$ salinities (31.40-31.80) were found (Lines A - C). This demonstrates that moderate salinity waters above the pycnocline directly lessened the stability of the pycnocline.

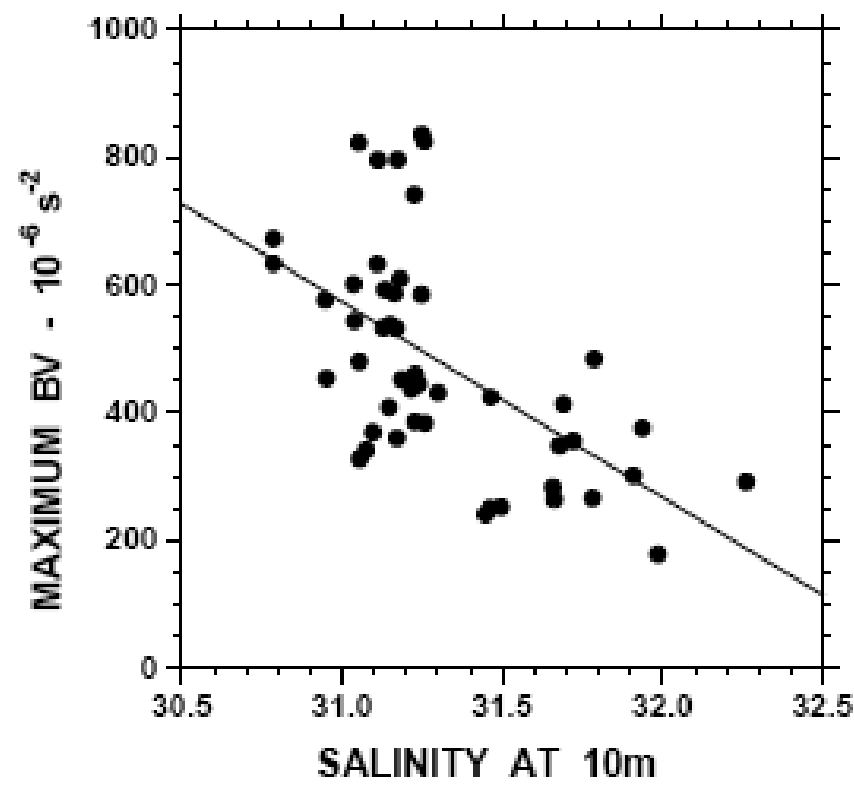

Fig. (13). The maximum Brunt Vaisala frequency in the primary pycnocline versus the salinity at $10 \mathrm{~m}$. The line was the linear regression, $\mathrm{BV}_{\max }=-306.53 \times \mathrm{S}+10076$. The slope was statistically significant $(\mathrm{P}>0.01$, Student's T test $)$.

\section{Richardson Numbers}

The value of the Brunt Vaisala frequency by itself does not tell if vertical mixing through the pycnocline is more likely, because rates of diapycnal mixing depend both on the strength of the pycnocline and the available kinetic energy. Kinetic energy in a stably stratified water column is proportional to the square of the vertical velocity shear $(\partial \mathrm{u} / \partial \mathrm{z})^{2}$. The gradient Richardson number is a parameter which scales the pycnocline strength to the available kinetic energy [54],

$\mathrm{Ri}=\mathrm{N}^{2} /\left((\partial \mathrm{u} / \partial \mathrm{z})^{2}\right)$

In this equation, $\mathrm{N}^{2}$ with units of $\mathrm{s}^{-2}$ is the pycnocline stability defined in equation 1 , and $\partial \mathrm{u} / \partial \mathrm{z}$ is the vertical shear $\left(\mathrm{s}^{-1}\right)$ in the horizontal current velocity. In theory, a large Richardson number describes the case where turbulence is suppressed, a smaller number indicates increased turbulence, and values $<1$ are required for turbulent mixing [54]. 
We used the Richardson number as a qualitative indicator to locate areas where the pycnocline was more or less stable. In this context, we accepted the observations that the two major currents which would drive vertical shear were the currents in the surface layer above the pycnocline $(10 \mathrm{~m}$, Fig. 10) and the strong flow found in the Beaufort shelfbreak jet below the pycnocline $(110 \mathrm{~m}$, Fig. 10). These two vertical zones dominate the flow patterns and would set the boundaries for establishment of velocity shear in the intervening layers. Note that our approach may differ from other studies in that vertical shear is typically evaluated based on velocities between adjacent layers. With our approximation, the denominator of equation 6 was evaluated as,

$(\partial \mathrm{u} / \partial \mathrm{z})^{2}=\left(\left(\mathrm{u}_{\mathrm{s}}-\mathrm{u}_{\mathrm{j}}\right) / \Delta \mathrm{z}\right)^{2}$,

where $u_{s}$ is the current vector in the surface layer, $u_{j}$ is the current vector in the layer containing the Beaufort shelfbreak jet, and $\Delta \mathrm{z}$ is the vertical distance $(100 \mathrm{~m})$ between the two horizontal layers. The quantity, $\left(\mathrm{u}_{\mathrm{s}}-\mathrm{u}_{\mathrm{j}}\right)$, represents the difference in current vectors at each grid site, yielding a map of the velocity shear (Fig. 14 top). Low values of the velocity shear $\left(<0.00005 \mathrm{~s}^{-1}\right)$ were found in the northeast corner of the sampling grid. High values $\left(>0.0018 \mathrm{~s}^{-1}\right)$ were found in the southern and central portions of the grid. Between these low and high values, the kinetic energy available from this vertical shear $\left((\partial \mathrm{u} / \partial \mathrm{z})^{2}\right)$ had more than a 1200 -fold range in intensity $\left(\left(0.0018^{2}\right) /\left(.00005^{2}\right)=1296\right)$.

Our estimate of the pycnocline's Richardson number, which we call the fixed-boundary Richardson number, $\mathrm{Ri}^{*}$, was developed based on a gridded map of the Brunt-Vaisala frequency data in Fig. (11 bottom) and the gridded map of velocity shear between 10 and $110 \mathrm{~m}$ (Fig. 14 top). With these two maps, $\mathrm{Ri}^{*}$ was calculated at every grid point (Fig. 14 bottom). The lowest value of $\mathrm{Ri}^{*}$ was 30 , while over $6 \%$ of the grid points had values exceeding 10000. Thus, the dynamic range in $\mathrm{Ri}^{*}$ was greater than 300 fold. Highest values were found in the offshore areas, in the northeast and northwest corners of the grid. Lowest values were found in the central and southern portion of the grid associated with the two eddies. In Fig. (14 bottom), selected salinity contour lines from the $10 \mathrm{~m}$ salinity distribution (Fig. 11 bottom) were superimposed. Interestingly, the centers of the major shallow dynamic features, including the eddy at CTD 6 and 13 as well as the central northward axis of the $10 \mathrm{~m}$ salinity plume, had moderately low Ri* values, values $<100$. The patches of lowest $\mathrm{Ri}^{*}$ were found along the boundaries of the $10 \mathrm{~m}$ salinity plume where shear was the greatest. Thus, the intense near-surface mesoscale field had a profound affect in lowering the $\mathrm{Ri}^{*}$ values across the pycnocline.

\section{DISCUSSION}

Past studies have shown that the northern Alaskan shelf break is associated with moderate currents and several different waters [22,31-33,55]. In springtime of 2003, we sampled 42 sites in the mesoscale region on the Beaufort Sea shelf break. We found evidence of both short-term temporally changing patterns as well as geographically fixed patterns. Our property-property plots showed that many of the water characteristics were highly correlated with salinity

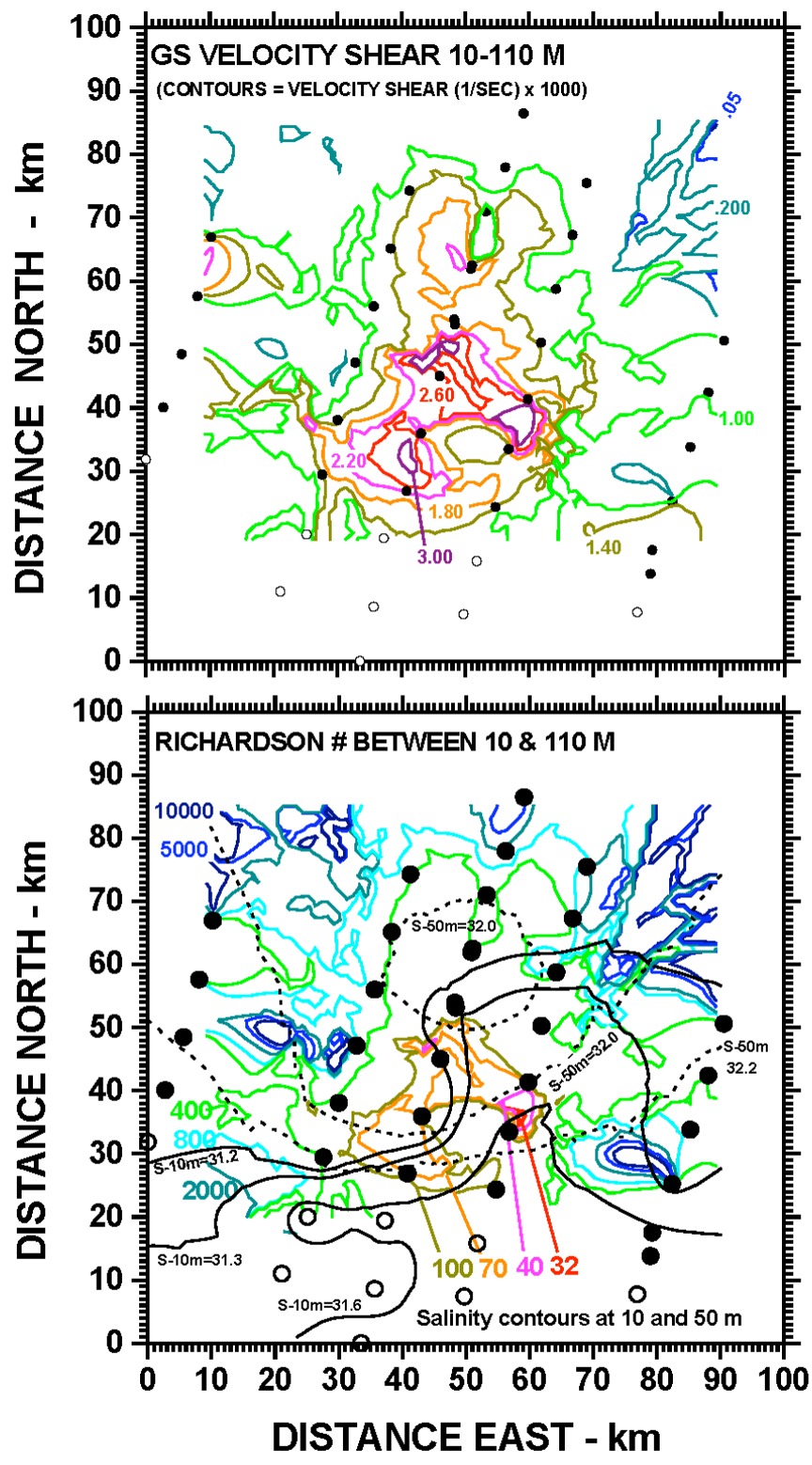

Fig. (14). Top: Map of the vertical velocity shear between 10 and $110 \mathrm{~m}$. Displayed contours range between $0.05 \times 10^{-3} \mathrm{~s}^{-1}$ and $3.0 \mathrm{x}$ $10^{-3} \mathrm{~s}^{-1}$. Bottom: Map of $\mathrm{Ri}^{*}$ (unitless). The contour lines between 32 and 10000 are displayed. Selected contours of salinities at $10 \mathrm{~m}$ depth (solid black lines) and $50 \mathrm{~m}$ (dotted black lines) have their the salinity value listed.

(Figs. 4-7), so that most of the sampled waters were differentiated into well-defined and previously characterized water masses [19,22,31,48,56]. However, we also found anomalies in nutrient properties that helped us identify transient waters in the study grid. The strongest physical feature in our study area was the Beaufort shelfbreak jet with current flows reaching $20 \mathrm{~cm} \mathrm{~s}^{-1}$ (Fig. 10). For waters in this jet, the fastest travel time through our sampling grid $(90 \mathrm{~km}$ along the shelf edge) would have been 5.2 days. Many of the waters were flowing much more slowly, so that our two week sampling period would likely capture the geographic distribution of the major stable features. As evidence of this, we located two small eddies about $20 \mathrm{~km}$ and $45 \mathrm{~km}$ north of the shelf break (Fig. 10). The properties of the deeper 
offshore eddy were identical between the first sampling on April 3 and the second sampling on April 9. Thus, we concluded that the hydrographic features in this mesoscale study area were relatively stable and that the distribution of water masses was tightly linked to the mesoscale physical features.

\section{Temperature, Salinity, and Nitrate}

Diagrams of potential temperature versus salinity have been the main tool for evaluation of water masses, yet in our study, we found that nitrate concentrations were equally useful. We employed a new spectrophotometric sensor for measuring sea water nitrate concentrations (ISUS) that allowed us to develop continuous profiles of nitrate concentrations in concert with temperature and salinity profiles [37,38]. By developing three-dimensional property plots (potential temperature, salinity, and nitrate, Fig. 5), eight different water masses were easily identified (Table 2). Nearly all bottle samples and nearly all portions of the continuous profiles matched this sequence of water masses.

Some waters were found which did not conform to the typical sequence of water masses. A sequence of stations next to the upper continental slope had intrusions of low nitrate water at 80-106 dbar. The three-dimensional property plots (Fig. 5) showed that the core of these intrusions had depth-varying salinities, but potential temperatures decreased nearly to the freezing point and nutrient concentrations stayed relatively invariant with increasing salinity (Fig. 4). The near-freezing temperatures suggested that these waters had been formed by salinization of surface water during ice formation $[31,52,57,58]$. Most sea-ice has quite low salinity (about $4-5,[39,52]$ ), so that as new sea ice forms in open leads within the pack ice, salty brines are rejected from the newly formed ice structure. These brines cascade downward, possibly mixing with surrounding seawater, until they reach waters of equal density [31,57,59]. At these cold temperatures, density is primarily determined by salinity, and as a result, when these intrusions reach a depth of equal density, they would have salinities that closely matched the preexisting layer. In contrast to salinity, the subsurface water masses had high nutrient concentrations, so that the convective intrusions were detected most readily by their relatively low nutrient concentrations. Once at a stable depth, the intruding waters would be advected with the general circulation and would be acted upon by both horizontal and vertical mixing. Mixing would do little to alter the intrusion's salinity. However, since the nutrient concentrations are less in the intrusion relative to the surrounding waters, mixing acting over time would raise the intrusion's nutrient content. In accordance with these expectations, we saw the intrusions with the lowest nutrients occurring over the broadest depth zone on the western end of our study area (transect line E). The intrusions became less broad and the minimum nitrate concentrations were less different from the surrounding waters on the successive eastward transect lines. This trend was explainable simply by continued mixing of the intrusion's waters as they were transported eastward.

\section{Dissolved Silicate}

The second anomalous water type we observed was the low silicate waters that had normal nitrate concentrations
(Fig. 6). Because their silicate concentrations were relatively invariant over the large range of salinities, and temperatures decreased toward the freezing point, these silicate anomaly waters probably were also formed from surface waters in a manner analogous with the nitrate anomaly waters. But the different proportions of silicate to nitrate suggested that they were from a different source. These waters were located in the approximate vicinity of the two eddies, and since export of these waters out of our sampling area would have taken more time, they were probably older than the nitrate anomaly waters.

\section{${ }^{18} \mathrm{O} /{ }^{16} \mathrm{O}$ Isotope Ratios}

The isotopic content of seawater has been used to evaluate the extent of fresh water loss from sea ice formation. In our samples, $\delta^{18} \mathrm{O}$ values correlated directly with salinity but with a relatively large variability $(+/-1 \%$, Fig. 7). Although we found three water masses which should have been greatly influenced by ice formation (nitrate anomaly waters, silicate anomaly waters, and waters near the freezing point), these water masses did not differentiate themselves from the remainder of the samples based on their oxygen isotopic content. Perhaps the large natural variability of $\delta^{18} \mathrm{O}$ in summertime waters of the Chukchi Sea [21] was the cause of our variability. Nevertheless, our oxygen isotope data suggested that the low saline surface waters experienced the greatest amount of sea-ice growth, $8.1 \mathrm{~cm}$ of sea-ice growth from a meter high column of original sample water. This degree of ice formation was intermediate between the results for the Canadian Beaufort Sea (11-17 cm of ice $\mathrm{m}^{-1}$, [52]) and the central Arctic (3-6 $\mathrm{cm} \mathrm{m}^{-1}$, [51]).

\section{Vertical Sections and Salinity}

The major characteristic of our vertical sections (e.g. Figs. 9, 10) was the uplift in shallow $(<120 \mathrm{dbar})$ contour lines of salinity and nitrate near to the shelf break and onto the shelf itself. By mapping the salinity distribution at several depths, considerable structure in the upwelling was discovered. The maps of salinity at 10, 50, and $110 \mathrm{~m}$ depths showed that highest salinities were found on the inshore sites, either on the shelf or at the shelf break and that the eastern three transects (lines A-C) were most significant (Fig. 10). The $10 \mathrm{~m}$ distribution (Fig. 10A) showed that a ridge of moderate salinities, between 31.40 and 31.80 , were located along the shelf break from transect line A through transect line D, outlining the region along the shelf break in which upwelling to this shallow depth was most extensive. A plume of this moderate-salinity water extended $40 \mathrm{~km}$ north of the shelf break along transect line B. The $50 \mathrm{~m}$ distribution showed upwelling of highest salinity $(>32.4)$ occurring at the shelf break on transects A-C (Fig. 10B). The $50 \mathrm{~m}$ distribution clearly outlined the two central eddies, the near-shore shallow one as a core of low salinity water and the deeper offshore one as a bolus of higher salinity water. The $110 \mathrm{~m}$ distribution also demonstrated the upwelling of higher salinity waters $(>33.2)$ at the shelf edge primarily on transect line B (Fig. 10C). We concluded that moderate salinity waters were being upwelled primarily along the eastern three transects centered on line B and that the shallow upwelled waters were being exported from the continental shelf in the region of transect lines A and B. 
It could be suggested that the positioning of higher salinity waters inshore on the continental shelf, as shown in the salinity maps (Fig. 10), may have been generated either if dense waters were being formed inshore or if other sources of higher salinity waters existed inshore and were leaking out across the shelf [60-62]. We did not sample further inshore than the stations shown, so conditions further inshore are unknown. One would expect that these inshore waters would have been at the freezing point if they had acquired salinities as high as 32.5 by sea-ice formation and salinization. However, our vertical profiles of the temperature above the freezing point at our most inshore station on each transect showed that only the surface waters were close to freezing and that the temperature above freezing actually increased with depth to the shallow seafloor (Fig. 8). Thus, most of the waters on the inshore end of each transect were not at the freezing point. In addition, we easily identified anomalous waters by their differences in nutrient properties. The water in the $10 \mathrm{~m}$ salinity plume along transect line B corresponded with our normal water types. Hypothetical pools of inshore water would likely not have nutrient-salinity relationships matching our normal patterns, since such waters typically have a higher proportion of river runoff. We conclude that the waters contained within the $10-\mathrm{m}$ export plume most likely were mixtures of the deeper slope waters and the well-characterized surface waters.

\section{Mesoscale Distributions of Geostrophic Currents}

The maps of geostrophic velocity (Fig. 10) demonstrated the complexity of the mesoscale physical field by showing three important features within the area. The key physical feature was the Beaufort shelfbreak jet, which had its dynamic core at about $100 \mathrm{dbar}$ and resided within $20 \mathrm{~km}$ of the shelf break (Fig. 10C) and it impacted flows between 50 and $260 \mathrm{~m}$. We also found two stationary eddies in the center of our sampling grid. These eddies were identifiable in the geostrophic velocity maps at several depth levels. The shallow inshore eddy near CTD 6 had counterclockwise flow $\left(10-20 \mathrm{~cm} \mathrm{~s}^{-1}\right)$ around low salinity water at $0-30 \mathrm{~m}$ depths. The deeper eddy, at $45 \mathrm{~km}$ from the shelf break at CTD 9 and CTD 24, had strong clockwise rotating geostrophic velocities $\left(10-20 \mathrm{~cm} \mathrm{~s}^{-1}\right)$. This eddy core was centered at $100-125 \mathrm{dbar}$ and had temperatures within $0.02^{\circ} \mathrm{C}$ of the freezing point. As the third feature, the maps demonstrated onshore and offshore flows of near-surface waters across the continental shelf. The flows at $10 \mathrm{~m}$ showed currents directed onto the shelf between transect lines $\mathrm{B}$ and $\mathrm{D}$, while offshore flow was found between lines A and B (Fig. 10A).

\section{The Mesoscale Distribution of Nitrate}

It has been suggested that the northern Chukchi Sea, the Beaufort Sea, and the southern Canada Basin all have oligotrophic productivities because the surface waters lack high nutrient concentrations and the strong primary pycnocline prevents significant input of deep-water nutrients $[27,62,63]$. Our vertical sections (Fig. 9) showed a general uplift in salinity and nutrient contour lines in the region near the shelfbreak (including its jet). To examine the nitrate distribution over a depth-range which approximated the summer-time euphotic zone [7,27], we evaluated the depthaveraged nitrate content over the upper $40 \mathrm{~m}$ and found it varied three fold, from 2.09 to $6.14 \mu \mathrm{M}$. The distribution of these nitrate concentrations showed that most of the moderate and higher concentrations were found near the shelf break and over the strong eddy (Fig. 11 top), and a strong statistical relationship was found between average nitrate concentrations in the upper $40 \mathrm{~m}$ and the salinity at 50 $\mathrm{m}$. Consequently, associated with the upwelling along the Beaufort Sea shelf break, the shelf break dynamics appeared strong enough to significantly enhance nutrients concentrations in the depth range of the summer euphotic zone.

\section{The Primary Pycnocline and Surface Nitrate}

The nutrient enrichment in the upper $40 \mathrm{~m}$ may have several linked causes. The correlation of nutrients with salinity would lead to the conclusion that any mechanism causing uplift of higher salinity waters into the summer-time euphotic zone would represent nutrient injection. But additional mechanisms that act on the positioning and strength of the primary pycnocline may also influence nutrients in the euphotic zone. We examined whether depth of the maximum Brunt Vaisala frequency was affected by the mesoscale physical field. A strong correlation between the pycnocline depth and salinity at $50 \mathrm{~m}$ (Fig. 12) indicated that the pycnocline depth varied from $>50 \mathrm{~m}$ in offshore areas to $<22 \mathrm{~m}$ in relation to the uplift of higher salinity waters. Thus, the vertical variations associated with the mesoscale field influenced both the salinity at $50 \mathrm{~m}$ and the position of the primary pycnocline.

In regards to the strength (stability) of the pycnocline, we observed a 4.7 fold difference in the maximum Brunt Vaisala frequency over the sampling grid, but the distribution of these values did not correlate with the salinity at $50 \mathrm{~m}$. Instead, lower values of the maximum frequency were found on the eastern side of our sampling grid and higher values were found on the western side of the grid (Fig. 11 bottom). As mirror opposites, we also found that a greater proportion of stations within $30 \mathrm{~km}$ of the shelf break on the eastern two transects had high nitrate concentrations in comparison with a lower proportion of high nitrate sites on the western two transects. In this regard, the occurrence of the moderatesalinity (31.40-31.80) plume at $10 \mathrm{~m}$ in the southeast sector would augment the nitrate concentrations found in the upper $40 \mathrm{~m}$, which could explain the greater nitrate concentrations on the eastern transects. In addition, the presence of this moderate salinity water at shallow depth would directly weaken the vertical stratification, and as anticipated, a strong relationship was found between the Brunt Vaisala frequency and salinity at $10 \mathrm{~m}$ (Fig. 13). Thus, the introduction of moderate salinity water at shallow depth would both add nutrients as well as weaken the pycnocline. This latter result could possibly promote greater diapycnal transport of both nutrients and salt on the eastern transect lines relative to those with more stable pycnoclines found in the western transects.

However, the value of the Brunt Vaisala frequency by itself does not tell if vertical mixing through the pycnocline is more likely, since rates of diapycnal mixing depend both on the strength of the pycnocline and the available kinetic energy. In this regard, the Richardson number is useful because it is the ratio of the Brunt Vaisala frequency to the square of the vertical shear in velocity. Low values 
correspond to sites with significant current shear relative to the strength of the pycnocline, whereas sites with high values had little current shear around the very stable pycnocline. Our estimate of the Richardson number, designated the fixed-boundary Richardson number, $\mathrm{Ri}^{*}$, was based on the maps of geostrophic velocities at 10 and $110 \mathrm{~m}$ (Fig. 10), fixed depths that would bracket the pycnocline depth across the grid. Although these two depths are not directly adjacent, so may inaccurately depict the actual vertical velocity shear, these two layers define the major near-surface currents. Thus, the use of these two layers provides a fixed depth interval from which to estimate possible horizontal variability in velocity shear. Within our sampling grid, $\mathrm{Ri}^{*}$ values varied by over 300 -fold from values as low as 30 . Most of the offshore area of our grid had extremely high values (exceeding 10000), corresponding to the wellestablished stable conditions within the offshore Canada Basin. The mesoscale activity that we observed reduced the $\mathrm{Ri}^{*}$ values from its high offshore values to values of $<100$, a decrease of 100 fold. Our map of Ri* (Fig. 14 bottom) showed that patches of very low values $(<40)$ were associated with the plume of moderate salinity water at $10 \mathrm{~m}$ depth and were near the surface eddy centered at CTD 6 . Interestingly, the lowest $\mathrm{Ri}^{*}$ patches were found in the boundary regions rather than in the centers of these major physical features, sites where the horizontal flows had been intensified by the confluence of the features. As a result, the size of the low $\mathrm{Ri}^{*}$ patches tended to be smaller than eddies. It is in these patches that strong diapycnal mixing of salt and nutrients may be most likely to occur.

\section{Role of Shelf-Break Upwelling}

There has been a paucity of scientific literature investigating the role of upwelling in promoting productivity off the Alaskan north coast. Yet, upwelling events have been frequently reported here [23, 28-30]. These events inject high salinity offshore waters (Halocline or Atlantic waters) onto the shelves. Many of these literature reports were for Barrow Canyon, perhaps because ship access to this coastal area was much more common than for other areas [28-30,55,56,64]. Also, the Canyon provided multiple physical mechanisms for promoting upwelling, so that upwelling was frequent. Upwelling favorable winds, either from the east or north, have been cited as one important forcing mechanism $[22,30,56,65]$, but several alternative mechanisms have been implicated [55,56,66-68]. Christensen et al. [22] observed one large event where inundation of the northern shelf had a volume flow of $19 \%$ and nitrate influx of $58 \%$ as much per unit time as the major nutrient-rich inflow into the region, the $0.8 \mathrm{~Sv}$ northern flow through the Bering Strait $\left(1 \mathrm{~Sv}=10^{6} \mathrm{~m}^{3} \mathrm{~s}^{-1}\right)$. In this event, a significant chlorophyll response occurred in the boundaries between the nutrientrich upwelled waters and the nutrient-poor surface waters.

Although upwelling events within Barrow Canyon have been well documented, less studied but perhaps more ubiquitous upwelling may occur along the Beaufort Sea shelf break. Some of the earliest reports included upwelling activity here $[23,65]$ which may be linked to the Beaufort shelfbreak jet [33]. This current occurs in all seasons but its character changes depending on the waters within it [33]. When carrying warm Chukchi shelf water, strong flow occurs near the sea surface. When carrying winter trans- formed shelf waters, it is a mid-depth jet $(100-150 \mathrm{~m})$, but when carrying deeper Atlantic waters, it merges with the deeper eastward flow of the Atlantic Water. In the situations where it carries winter water or Atlantic Water, these waters may upwell near the shelf break. Since both water masses are high in nutrients $[22,23,30]$, this current could be significant in the vertical transport of nutrients. In addition, this current is conducive for baroclinic instabilities that may lead to potentially important mesoscale vertical transports. These instabilities may also be responsible for generating smallscale eddies ubiquitous in the Canada Basin [34-36].

During our sampling, we found the current was located at about 100 dbar and was carrying winter-transformed waters. Salinity and nitrate contour lines were uplifted in the shelf break region near the jet, and two small eddies were integral to the mesoscale field. Also associated with the upwelling, offshelf near-surface flows were observed. We showed significant nutrient enrichment in the surface waters as a result of the mesoscale processes. Given that this current occurs in all seasons, it could have year-round significance in enhancing the flux of nutrients into the near-surface waters. Since many of the physical features we saw had geometric scales of $<30 \mathrm{~km}$, they could be easily missed by random shipboard sampling.

A variety of separate physical mechanisms may be responsible for the role of the mesoscale field in supplying nutrients to the near-surface waters. We demonstrated the role of uplift of the isohaline contour lines and we also showed that introduction of moderate salinity waters above the main pycnocline both adds nutrients to the upper waters as well as weakens the pycnocline. In addition, our map of $\mathrm{Ri}^{*}$ demonstrates that significant vertical velocity shear found within an active mesoscale field can make the pycnocline more susceptible to turbulent breakdown. Our minimum value of $\mathrm{Ri}^{*}(30)$ did not reach the theoretical value $(<1)$ required for turbulent disruption of the pycnocline. The relatively large values of our $\mathrm{Ri}^{*}$ may have resulted in part from the large value of $\Delta \mathrm{z}$ in equation $7(100 \mathrm{~m})$ based on the choice of the two fixed boundaries $(10 \mathrm{~m}$ and $110 \mathrm{~m})$. However, since the same $\Delta \mathrm{z}$ was used throughout the maps of both shear and $\mathrm{Ri}^{*}$ (Fig. 14), the maps would provide a qualitative indicator of the impact of kinetic energy on the stability of the pycnocline. Nevertheless, it is likely that other mechanisms also contribute to the introduction of nutrients above the main pycnocline. Melling [69] and Melling and Lewis [57] describe the role of vertical convection of brines during ice formation in penetrating and weakening the pycnocline. Based on our ${ }^{18} \mathrm{O} /{ }^{16} \mathrm{O}$ data, the ice growth in our region was intermediate between that of the high growth region in the Canadian Beaufort Sea and the lower growth region in the central Arctic Ocean. So, vertical convection may be a significant factor particularly when the pycnocline is shallower due to mesoscale activity. Tidal forcing along the Alaskan Beaufort shelf is small [70,71] and not likely to be a significant contributor. Mixing by the passage of deep ice keels (typically as deep as $20 \mathrm{~m}$, [72]) may add to turbulence across the main pycnocline, especially when the pycnocline has been uplifted. Finally, greater turbulence due to increased roughness of both the sea-ice and the seafloor may increase the likelihood of pycnocline breakdown when the pycnocline is upwelled onto the shallow shelf. Our vertical sections (Fig. 8) demonstrated 
that the shallowest stations had temperatures above the freezing point by as much as $0.3^{\circ} \mathrm{C}$. Since the near-shore waters would be expected to have near-freezing temperatures, this additional heat represents the impact of the warmer more saline waters on the entire shelf water column. Consequently, the shelf itself may be a site of pycnocline disruption when the upwelling has moved the pycnocline onto the shelf.

\section{Nutrients and Productivity}

Our results demonstrate that nutrient injection into the surface waters near the Beaufort shelf break could be an important year-round process. But more specifically, we can use our data to estimate the possible productivity of the spring bloom. Since spring bloom productivity is considered to be driven by the wintertime accumulation of nutrients in the surface waters [73], the magnitude of this productivity may be estimated if the nitrogen content of the euphotic zone is known in the time period just preceding the bloom. Given our average nitrate content in the upper $40 \mathrm{~m}(4.28 \mu \mathrm{M}$, Fig. 11 top), assuming that all of this nitrate was consumed, and using the Redfield C:N atomic stoichiometry of 106:16, the nitrate-based production averaged over all of our continuous profiles would have been $13.6 \mathrm{~g}-\mathrm{C} \mathrm{m}^{-2}$ (standard deviation $=$ $+/-4.2,37$ profiles). Assuming that $80 \%$ of the spring bloom productivity was new production $[74,75]$, total production (new production and recycled production) would have equaled $17.0 \mathrm{~g}-\mathrm{C} \mathrm{m}^{-2}$. However, our results showed that upwelling may be more common near the shelf break. Subdividing our sites into those with $20 \mathrm{~km}$ of the shelf break versus those further offshore, the average bloom production would have been $18.3 \mathrm{~g}-\mathrm{C} \mathrm{m}{ }^{-2}$ near the shelf break (standard deviation $=+/-2.6, \mathrm{n}=14$ ) and $10.7 \mathrm{~g}-\mathrm{C} \mathrm{m}^{-2}$ offshore (standard deviation $=+/-1.6, n=23$ ). Correcting for total production, the total shelf edge production would have been $22.9 \mathrm{~g}_{-} \mathrm{C} \mathrm{m}^{-2}$ and the total offshore production would have been $13.4 \mathrm{~g}-\mathrm{C} \mathrm{m}^{-2}$.

In 2003, the Shelf-Basin Interactions Project conducted icebreaker cruises in the shelf break region of the western Beaufort and northern Chukchi Seas in both June and August, and primary productivity measurements were made via water sample incubations [27]. Annual productivities in the northern shelf were estimated to average about $70 \mathrm{~g}-\mathrm{C} \mathrm{m}^{-2} \mathrm{y}^{-1}$, and offshore sites in the southern Canada basin averaged $20 \mathrm{~g}-\mathrm{C} \mathrm{m}^{-2} \mathrm{y}^{-1}$. Hill and Cota [27] reported that the first icebreaker cruise arrived too late to assess the spring bloom, and by the first cruise, nitrate concentrations in the offshore surface waters were $<2 \mu \mathrm{M}$. Our helicopter based sampling occurred about 4 weeks earlier than the arrival of the icebreaker near the shelf edge. In order to correct the annual estimates of primary production for the spring bloom, our spring-bloom estimates of total production were added to the estimates of Hill and Cota [27]. Thus, the revised shelf and shelf edge annual production would have been $93 \mathrm{~g}-\mathrm{C} \mathrm{m}^{-2} \mathrm{y}^{-1}$, while the offshore annual production would have been $33.4 \mathrm{~g}-\mathrm{C} \mathrm{m}^{-2} \mathrm{y}^{-1}$. This would suggest that the shelf break region is more productive that previously believed. Considering that, in our study, the vertical supply of nutrients was closely related to mesoscale physics, and that the long cruise track of the icebreaker in 2003 resulted in relatively few productivity stations being occupied in any single mesoscale area, the shipboard productivity measure- ments may not have captured key upwelling or mesoscale events. Thus, the ship-based productivity measurements may perhaps be low of the actual production along the Beaufort Sea shelf break.

\section{CONCLUSIONS}

A mesoscale area on the Beaufort Sea shelf break was investigated in April 2003. Based on temperature, salinity, and nitrate concentrations, we identified eight different water masses whose properties remained invariant during the sampling period. In addition, two transient water masses were identified, those with anomalous low nitrate and silicate concentrations relative to the sample's salinity and those with anomalous low silicate concentrations but normal nitrate concentrations with respect to the sample's salinity. Both transients appeared to have been shallower water that had cooled to the freezing point and then had convected to depth. The ${ }^{18} \mathrm{O} /{ }^{16} \mathrm{O}$ isotopic ratios indicated that sea-ice growth of $8.1 \mathrm{~cm}$ of sea-ice per meter high column of original seawater occurred in the surface waters, intermediate between higher ice-growth areas in the Canadian Beaufort Sea and lower ice growth region of the central Arctic Ocean. Maps of salinity at several depths showed that higher salinity waters had upwelled above the Beaufort shelfbreak current and onto the shelf, and a plume of moderate salinity (31.4031.80 ) water at $10 \mathrm{~m}$ was exiting the shelf on the eastern side of the grid. The distribution of geostrophic velocities in our study grid demonstrated that the Beaufort shelfbreak jet was a moderately flowing $\left(20 \mathrm{~cm} \mathrm{~s}^{-1}\right)$ current centered at $100 \mathrm{dbar}$ within $20 \mathrm{~km}$ of the upper slope. Two small eddies (radius $10 \mathrm{~km}$ ) were trapped within our mesoscale field. One had counter-clockwise flow centered in the surface layer at about $20 \mathrm{~km}$ from the shelf break, and the other had clockwise flow and cold core temperatures centered at 120 dbar about $45 \mathrm{~km}$ from the shelf break. Repeated sampling of the stronger eddy showed that it was stationary during our experiment. The mesoscale field also impacted the depth of the primary pycnocline, raising it from $>50 \mathrm{~m}$ in the offshore sites to $<22 \mathrm{~m}$, where higher salinity waters had upwelled. In addition, nitrate concentrations in the upper $40 \mathrm{~m}$ were increased by three-fold in relation to these uplifts. The plume of moderate salinity water at $10 \mathrm{~m}$ caused the reduction in vertical stability of the pycnocline, and its boundaries contained small patches of low Richardson numbers. These patches may have been sites of increased diapycnal mixing of salinity and nutrients. Overall, the mesoscale dynamics strongly effected the upwelling of high nitrate water near and onto the Beaufort continental shelf. This sampling occurred just weeks before the anticipated spring productivity bloom, so the nutrient-rich waters near the shelf break would have promoted a stronger spring bloom, and subsequent upwelling potentially could have increased the nutrient supply following the bloom. Thus, the region near the Beaufort shelf break appears to be a site of greater annual productivity than found in the stratified waters offshore.

\section{ACKNOWLEDGEMENTS}

This research was supported by NSF grants \# 0125306, 0125313, and 0352641 to the authors. We thank Dr. C. Belzile for assistance, advice, and an illuminating critique. 


\section{ABBREVIATIONS}

$$
\begin{array}{ll}
\text { ARCSS } & =\text { Arctic system science program } \\
\text { CTD } & =\text { Conductivity, temperature, and depth } \\
\text { ISUS } & =\text { In situ ultraviolet spectrophotometer } \\
\text { SBI } & =\text { Shelf-basin interactions project } \\
\text { SHEBA } & =\text { Surface heat budget of the arctic project }
\end{array}
$$

\section{REFERENCES}

[1] Alexander V. In: Reed JC, Sater JE, Eds. Primary productivity regions of the nearshore Beaufort Sea, with reference to potential roles of ice biota. The coast and shelf of the Beaufort Sea. Arctic Institute of North America, Calgary Alberta 1974; pp. 609-32.

[2] Hameedi JJ. Aspects of water column primary productivity in Chukchi Sea during summer. Mar Biol 1978; 48: pp. 37-46.

[3] Horner R. In: Barnes P, Schell D, Reimnitz E. Eds. Phytoplankton abundance, chlorophyll a, and primary productivity in the western Beaufort Sea. The Alaskan Beaufort Sea: Ecosystems and Environments. Academic Press Inc., New York 1984; 295-310.

[4] Cota GF, Pomeroy LR, Harrison WG, et al. Nutrients, primary production and microbial heterotrophy in the southeastern Chukchi Sea: Arctic summer nutrient depletion and heterotrophy. Mar Ecol Prog Ser 1996; 135: 247-58.

[5] Pomeroy LR. Primary production in the Arctic Ocean estimated from dissolved oxygen. J Mar Syst 1997; 10: 1-8

[6] Sherr EB, Sherr BF, Wheeler PA, Thompson K. Temporal and Spatial variation in stocks of autotrophic and heterotrophic microbes in the upper water volume of the central Arctic Ocean. Deep-Sea Res 2003; 50: 557-71.

[7] Lee SH, Whitledge TE. Primary and new production in the deep Canada Basin during summer 2002. Polar Biol 2005; 28: 190-7.

[8] Subba Rao DV, Platt T. Primary production of Arctic waters. Polar Biol 1984; 3: 191-201.

[9] Smith WO, Harrison WG. New production in polar regions: the role of environmental controls. Deep-Sea Res 1991; 38: 1463-79.

[10] Gradinger R. Climate change and biological oceanography of the Arctic Ocean. Phil Trans R Soc Lond 1995; 352: 277-86.

[11] Gloersen P, Campbell WJ. Recent variations in Arctic and Antarctic sea-ice cover. Nature 1991; 352: 33-6.

[12] Gloersen P, Yu J, Mollo-Christensen E. Oscillatory behavior in Arctic sea ice concentrations. J Geophys Res 1996; 101: 6641-50.

[13] Comiso JC, Yang Y, Honjo S, Krishfield RA. Detection of change in the Arctic using satellite and in situ data. J Geophys Res 2003; 108 (C12): 3384.

[14] Serreze MC, Maslanik JA, Scambos TA, et al. A record minimum arctic sea ice extent and area in 2002. J Geophys Res Lett 2003; 30 (3): 1110.

[15] Rothrock DA, Yu Y, Maykut GA. Thinning of the Arctic Sea-Ice Cover. Geophys Res Lett 1999; 26 (23): 1-5.

[16] Rothrock DA, Zhang J, Yu Y. The arctic ice thickness anomaly of the 1990s: a consistent view from observations and models. J Geophys Res 2003; 108(C3): 3083.

[17] Perovich DK, Cota GF, Maykut GA, Grenfell TC. Bio-optical observations of first-year Arctic sea ice. Geophys Res Lett 1993; 20: $1059-62$.

[18] Perovich DK, Roesler C, Pegau WS. Variability in sea ice optical properties. J Geophys Res 1998; 103: 1193-208.

[19] Jones EP, Anderson LG. On the origin of the chemical properties of the Arctic Ocean Halocline. J Geophys Res 1986; 91: 10759-67.

[20] Macdonald RW, McLaughlin FA, Carmack EC. Freshwater and its sources during the SHEBA drift in the Canada Basin of the Arctic Ocean. Deep-Sea Res 2002; 49: 1769-85.

[21] Cooper LW, Whitledge TE, Grebmeier JM, Weingartner TJ. The nutrient, salinity, and stable oxygen isotope composition of Bering and Chukchi Seas waters in and near the Bering Strait. J Geophys Res 1997; 102: 12563-73.

[22] Christensen JP, Shimada K, Semiletov I, Wheeler PA. Chlorophyll response to shelf-break upwelling and winds in the Chukchi Sea, Alaska, in autumn. Open Ocean J 2008; 2: 34-53.

[23] Hufford GL. On apparent upwelling in the southern Beaufort Sea. J Geophys Res 1974; 79 (9): 1305-6.
[24] English TS. Some biological oceanographic observations in the central North Polar Sea, Drift Station Alpha, 1957-1958. Arctic Institute of North America Res Paper 1961; 13: 64.

[25] Macdonald RW, Carmack EC. Age of Canada Basin deep waters: a way to estimate primary productivity of the Arctic Ocean. Science 1991; 254: 1348-50.

[26] Macdonald RW, Carmack EC, Wallace DWR. Tritium and radiocarbon dating of Canada Basin deep waters. Science 1993; 259: 103-4.

[27] Hill V, Cota G. Spatial patterns of primary production on the shelf, slope and basin of the western Arctic in 2002. Deep-Sea Res II 2005; 52: 3344-54

[28] Bourke RH, Paquette RB. Atlantic water on the Chuykchi shelf. Geophys Res Lett 1976; 3: 629-32.

[29] Garrison GR, Paquette RG. Warm water interactions in Barrow Canyon in winter. J Geophys Res 1982; 87: 5853-9.

[30] Johnson WR. Current response to wind in the Chukchi Sea: a regional coastal upwelling event. J Geophys Res 1989; 94: 205764 .

[31] Aagaard K, Coachman LK, Carmack E. On the halocline of the Arctic Ocean. Deep-Sea Res 1981; 28A: 529-45.

[32] Aagaard K. In: Barnes PW, Schell DM, Reimnitz E, Eds. The Beaufort Undercurrent. The Alaskan Beaufort Sea: Ecosystems and Environments. Academic Press, New York 1984; pp. 47-71.

[33] Pickart RS. Shelfbreak circulation in the Alaskan Beaufort Sea: Mean structure and variability. J Geophys Res 2004; 109: C04024.

[34] Hunkins KL. Subsurface eddies in the Arctic Ocean. Deep-Sea Res 1974; 21: 1017-33

[35] Manley TO, Hunkins K. Mesoscale eddies of the Arctic Ocean. J Geophys Res 1985; 90: 4911-30.

[36] Muench RD, Gunn JT, Whitledge TE, Schlosser P, Smethie W. An Arctic Ocean cold core eddy. J Geophys Res, 2000; 105: 239974006.

[37] Johnson KS, Coletti LJ. In situ ultraviolet spectrophotometry for high resolution and long-term monitoring of nitrate, bromide and bisulfide in the ocean. Deep-Sea Res 2002; 49: 1291-305.

[38] Christensen JP, Melling H. Correcting nitrate profiles measured by the in situ Ultraviolet Spectrometer in Arctic Ocean waters. Open Ocean J 2009; 3: 59-66.

[39] Ostlund HG, Hut G. Arctic Ocean water mass balance from isotope data. J Geophys Res 1984; 89: 6373-81.

[40] Christensen J, Melling H, 2003 Helo Survey CTD Data. Data report in the ARCSS data repository. [cited 2010 Jan 10] http://data.eol.ucar.edu/codiac/dss/id=62.292

[41] Millero FJ, Leung WH. The thermodynamics of seawater at one atmosphere. Am J Sci 1976; 276: 1035-77.

[42] Smethie WM, Schlosser P, Bonisch G, Hopkins TS. Renewal and circulation of intermediate waters in the Canadian Basin observed on the Scicex 96 cruise. J Geophys Res 2000; 105: 1105-21.

[43] Gill AE. Atmosphere-Ocean Dynamics. Academic Press, New York 1982; p. 662

[44] Christensen J, Melling H. 2003 Helo Survey ISUS Nitrate Concentrations, Temperature, Salinity, and Density. Data report in the ARCSS data repository. [cited 2010 Jan 10] http://data.eol.ucar. edu/codiac/dss $/$ id $=62.312$

[45] Christensen J, Melling H. 2003 Helo Survey Nutrients and Oxygen Isotope Samples. Data report in the ARCSS data repository. [cited $2010 \mathrm{Jan}$ 10] http://data.eol.ucar.edu/codiac/dss/id=62.311

[46] Coachman LK, Aagaard K. In: Herman Y. Ed. Physical oceanography of Arctic and subarctic seas. Marine Geology and Oceanography of the Arctic Seas. NY: Springer Verlag, 1974; pp. $1-72$

[47] Swift JH, Jones EP, Aagaard K, et al. Waters of the Makarov and Canada Basins. Deep-Sea Res 1997; 44: 1503-30.

[48] Melling H. Hydrographic changes in the Canada Basin of the Arctic Ocean, 1979-1996. J Geophys Res 1998a; 103: 7637-45.

[49] Tan FC, Strain PM. The distribution of sea ice meltwater in the Eastern Canadian Arctic. J Geophys Res 1980; 85: 1925-32.

[50] Bedard P, Hillaire-Marcel C, Page P. 180 modelling of freshwater input in Baffin Bay and Canadian Arctic coastal waters. Nature (London) 1981; 293: 287-9.

[51] Moore RM, Lowings MG, Tan FC. Geochemical profiles in the central Arctic Ocean: their relation to freezing and shallow circulation. J Geophys Res 1983; 88: 2667-74. 
[52] Melling H, Moore RM. Modification of halocline source waters during freezing on the Beaufort Sea shelf: Evidence from oxygen isotopes and dissolved nutrients. Cont Shelf Res 1995; 15: 89-113.

[53] Sokal RR, Rohlf FJ. Biometry: the principles and practice of statistics in biological research. San Francisco: W.H. Freeman 1969; p. 776.

[54] Neuman G, Pierson WJ. Principles of Physical Oceanography. Prentice Hall, Englewood Cliffs NJ 1966; p. 545.

[55] Pickart RS, Weingartner TJ, Pratt LJ, Zimmermann S, Torres DJ. Flow of winter-transformed Pacific water into the western Arctic. Deep-Sea Res 2005; 52: 3175-98.

[56] Weingartner TJ, Cavalieri DJ, Aagaard K, Sasaki Y. Circulation, dense water formation, and outflow on the northeast Chukchi shelf. J Geophys Res 1998; 103: 7647-61.

[57] Melling H, Lewis EL. Shelf drainage flows in the Beaufort Sea and their effect on the Arctic Ocean pycnocline. Deep-Sea Res 1982; 29: 967-85.

[58] Moore RM, Melling H, Thompson KR. A description of water types on the Mackenzie shelf of the Beaufort Sea during winter. J Geophys Res 1992; 97: 12607-18.

[59] Gawarkiewicz G, Chapman DC. A numerical study of dense water formation and transport on a shallow, sloping continental shelf. J Geophys Res 1995; 100: 4489-508.

[60] Macdonald RW, Carmack EC, McLaughlin FA, Iseki K, Macdonald DM, O'Brien MC. Composition and modification of water masses in the Mackenzie Shelf Estuary. J Geophys Res 1989; 94: 18057-70.

[61] Macdonald RW, Paton DW, Carmack EC, Omstedt A. The freshwater budget and under-ice spreading of Mackenzie River Water in the Canadian Beaufort Sea based on salinity and 18O/16O measurements in water and ice. J Geophys Res 1995; 100: 895-919.

[62] Macdonald RW, Carmack EC, McLaughlin FA, Falkner KK, Swift $\mathrm{JH}$. Connections among ice, runoff and atmospheric forcing in the Beaufort Gyre. Geophys Res Lett 1999; 26: 2223-6.
[63] Macdonald RW, Wong CS, Erickson PE. The distribution of nutrients in the southeastern Beaufort Sea: Implications for water circulation and primary productivity. J Geophys Res 1987; 92: 2932-52.

[64] Mountain DB, Coachman LK, Aagaard K. On the flow through Barrow Canyon. J Phys Ocean 1976; 6: 461-70.

[65] Mountain DG. In: Reed JC. Sater JE. Eds Preliminary analysis of Beaufort Shelf circulation in summer. The coast and shelf of the Beaufort Sea. Arctic Institute of North America, Arlington VA 1974; pp. 27-48.

[66] Aagaard K, Roach AT. Arctic Ocean-shelf exchange: Measurements in Barrow Canyon. J Geophys Res 1990; 95: 18163-75.

[67] Munchow A, Carmack EC. Synoptic flow and density observations near an Arctic shelf break. J Phys Ocean 1997; 27: 1402-19.

[68] Signorini SR, Munchow A, Haidvogel D. Flow dynamics of a wide Arctic canyon. J Geophys Res 1997; 102: 18661-80.

[69] Melling $\mathrm{H}$. The formation of a haline shelf front in wintertime in an ice-covered arctic sea. Cont Shelf Res 1993; 13: 1123-47.

[70] Kowalik Z, Proshutinsky AY. Diurnal tides in the Arctic Ocean. J Geophys Res 1993; 98(C9): 16449-68.

[71] Kowalik Z, Proshutinsky AY. In: Johannessen OM, Muench RD. Overland JE. Eds. The Arctic Ocean tides. The Polar Oceans and their Role in Shaping the Global Environment. AGU, Washington D.C. 1994; pp. 137-58.

[72] Melling H. Detection of features in first-year pack ice by synthetic apeture radar (SAR). Int J Remote Sens 1998b; 19: 1223-49.

[73] Russell-Hunter WD. Aquatic Productivity: An introduction to some basic aspects of biological oceanography and limnology. CollierMacmillan, London 1970; p. 306.

[74] Epply RW, Peterson BJ. Particulate organic matter flux and planktonic new production in the deep ocean. Nature (London) 1979; 282: 677-80.

[75] Harrison WG, Platt T, Irwin B. Primary production and nutrient assimilation by natural phytoplankton populations of the eastern Canadian Arctic. Can J Fish Aquat Sci 1982; 39: 335-45. 